\title{
BUKU AJAR \\ KOMUNIKASI LINTAS BUDAYA
}

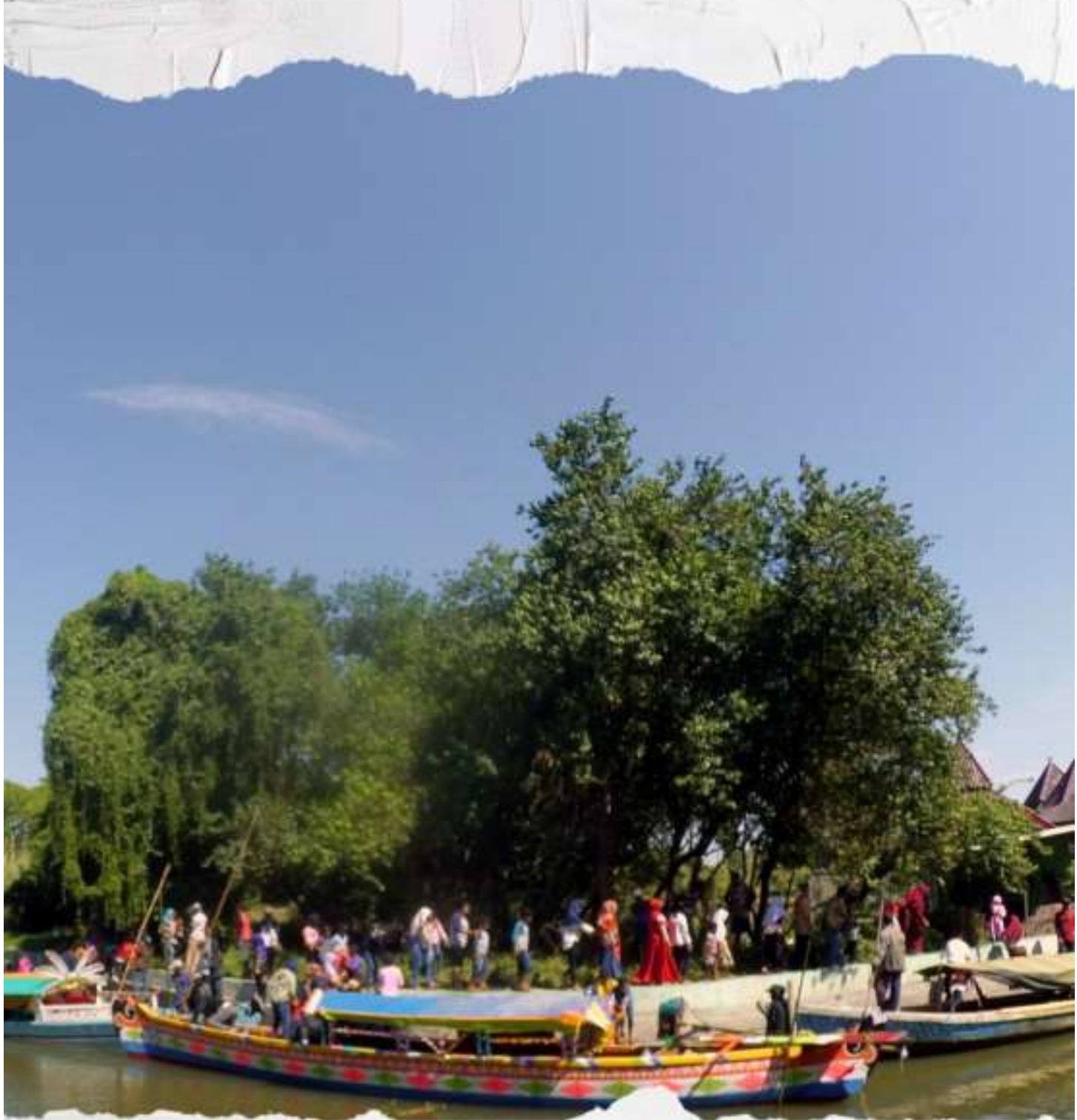




\title{
Buku Ajar \\ Komunikasi Lintas Budaya
}

\author{
Penulis:
}

Didik Hariyanto dan Ferry Adhi Dharma

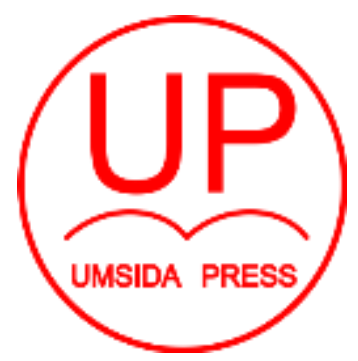

Diterbitkan oleh UMSIDA PRESS

Jl. Mojopahit 666 B Sidoarjo

ISBN: 978-623-6833-02-5

Copyright@2020.

\section{Didik Hariyanto dan Ferry Adhi Dharma}

All rights reserved 
Buku Ajar

\section{Komunikasi Lintas Budaya}

\section{Penulis :}

Didik Hariyanto dan Ferry Adhi Dharma

\section{ISBN :}

978-623-6833-02-5

\section{Editor :}

Septi Budi Sartika

M. Tanzil Multazam

\section{Copy Editor :}

Fika Megawati

Design Sampul dan Tata Letak :

Mochamad Nashrullah

\section{Penerbit :}

UMSIDA Press

\section{Redaksi :}

Universitas Muhammadiyah Sidoarjo

Jl. Mojopahit No 666B

Sidoarjo, Jawa TImur

\section{Cetakan pertama, Agustus 2020}

(C) Hak cipta dilindungi undang-undang

Dilarang memperbanyak karya tulis ini dengan suatu apapun tanpa ijin tertulis dari penerbit. 


\section{KATA PENGANTAR}

Alhamdulillah, segala puji dan syukur bagi Allah SWT karena buku ajar Komunikasi Lintas Budaya ini dapat terselesaikan dengan baik. Terimakasih juga penulis sampaikan pada Universitas Muhammadiyah Sidoarjo yang telah mempercayakan tanggungjawab penyusunan buku ajar ini pada penulis melalui program Riset Dasar Institusi.

Buku ini dibuat dalam situasi yang tidak biasa, yakni terjadinya wabah global Sars-Cov-2 atau yang kita kenal sebagai virus corona sehingga banyak konsentrasi penulis yang terpecah akibat deadline-deadline pekerjaan lain yang semakin menumpuk dalam proses belajar-mengajar online.

Dalam buku ini penulis mencoba mengkaji berbagai literatur dalam kajian komunikasi, sosial, dan budaya sebagai satu-kesatuan yang mendasari terbentuknya komunikasi lintas budaya. Berbagai topik dalam buku ini menggambarkan peranan dari 3 (tiga) kajian rumpun ilmu sosial seperti: definisi komunikasi lintas budaya, kajian tentang folklor, unsur-unsur budaya, konstruksi realitas sosial, hingga komodifikasi budaya. 
Penulis sungguh menyadari jika buku ajar ini memiliki berbagai kekurangan. Karenanya, kritik dan saran daripembaca sangat penulis butuhkan sebagai uapaya perbaiakan pada penulisan selanjutnya. Semoga buku ini bermanfaat bagi pembaca, kususnya mahasiswa dan menjadi sebuah amal ibadah bagi penulis.

Sidoarjo, 30 Juli 2020

Tim Penulis,

Dr. Didik Hariyanto, S.S.os., M.Si 
KATA PENGANTAR

\section{BAB 1 DEFINISI KOMUNIKASI LINTAS BUDAYA}

A. Komunikasi Lintas Budaya ........................................2

B. Fungsi Komunikasi Lintas Budaya...............................6

\section{BAB 2 INTERAKSIONISME SIMBOLIK}

A. Definisi Interaksionisme Simbolik ...............................15

\section{BAB 3 AKULTURASI DAN SISTEM KEBUDAYAAN}

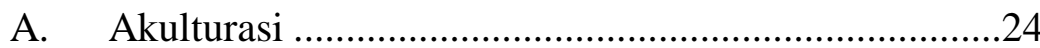

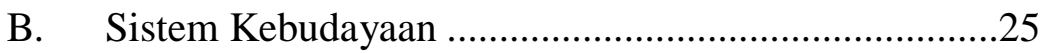

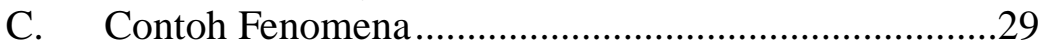

\section{BAB 4 KAJIAN TENTANG FOLKLORE}

A. Definisi Umum Folklor ...............................................

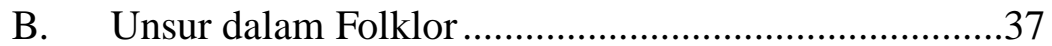

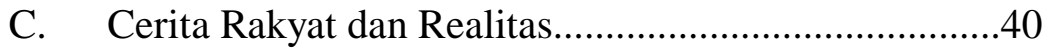

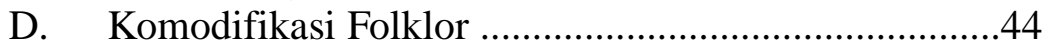

E. Folklor dan Pariwisata ..................................................46

BAB 5 KOMUNIKASI DAN KONSTRUKSI SOSIALBUDAYA

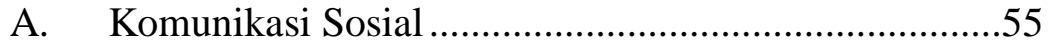

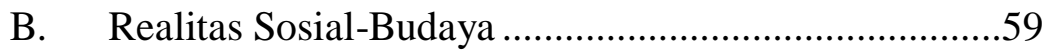

\section{BAB 6 FENOMENOLOGI}

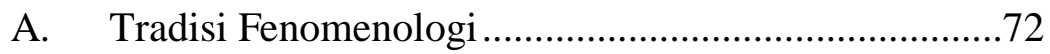

B. Edmund Husserl ........................................................

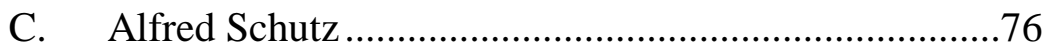

D. Peter L. Berger dan Thomas Luckmann ........................78 


\section{BAB 7 STUDI GENDER DALAM KOMUNIKASI LINTAS BUDAYA}

A. Makna Gender dalam Komunikasi Lintas

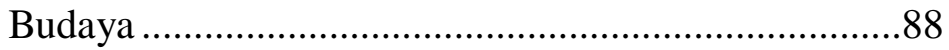

\section{BAB 8 ETNOGRAFI KOMUNIKASI}

A. Etnografi dan Etnografi Komunikasi...........................95

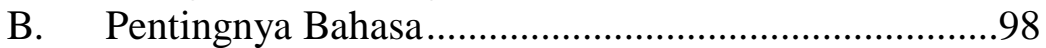

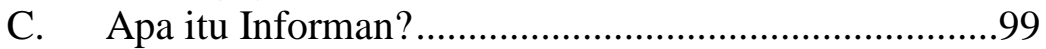

D. Membuat Catatan Etnografis .....................................103

E. Mengajukan Pertanyaan Deskriptif ...........................104

F. Melakukan Analisis ..................................................105

G. Menulis Laporan Etnografi ........................................112

\section{BAB 9 ETNOGRAFI VIRTUAL}

A. Komunikasi Virtual ...............................................117

B. Prinsip Etnografi Virtual ...........................................123

C. Langkah-Langkah Etnografi Virtual...........................127

\section{Biografi Penulis}




\section{BAB 1 \\ DEFINISI KOMUNIKASI LINTAS BUDAYA}

\section{Tujuan Instruksional Umum}

Setelah menyelesaikan Bab 1 mahasiswa diharapkan mampu:

1. Memahami pengertian komunikasi lintas budaya.

2. Memahami tujuan dan pentingnya studi komunikasi lintas budaya.

3. Memahami beberapa pandangan mengenai studi komunikasi lintas budaya.

\section{Tujuan Instruksional Khusus}

Setelah mempelajari dan mengerjakan evaluasi di akhir Bab 1 ini mahasiswa diharpkan mampu:

1. Menjelaskan pengertian komunikasi lintas budaya.

2. Menjelaskan tujuan dan urgensi mempelajari komunikasi lintas budaya.

3. Mendiskusikan dan menjelaskan pandanganpandangan mengenai studi komunikasi lintas budaya. 


\section{A. Komunikasi Lintas Budaya}

Secara umum komunikasi lintas budaya merupakan istilah yang sering diapaki untuk menjelaskan makna dari komunikasi antar budaya, yang tidak terbatas oleh konteks geogafis, ras dan etnik. Komunikasi lintas budaya didefinisikan sebagai analisis perbandingan yang memprioritaskan relativitas kegiatan kebudayaan. Oleh karenanya, komunikasi lintas budaya lebih terfokus pada hubungan komunikasi antar bangsa dengan tidak memunculkan kultur baru sperti dalam kajian komunikasi antar budaya (Purwasito, 2003).

\section{Stella Ting-Toomey (1999) mendefinisikan} komunikasi lintas budaya sebagai proses pertukaran makna antar individu atau dalam komunitas budaya yang berbeda (lintas budaya) untuk menegosiasikan makna bersama dalam situasi interaktif. Perbedaan latar belakang sosial budaya seringkali menjadi hambatan dalam proses komunikasi, karena adanya standar baik, buruk, benar, dan salah yang berbeda di tiap budaya. Oleh karenanya, penting mempelajari komunikasi lintas budaya untuk saling beradaptasi 
terhadap nilai-nilai sosial budaya yang baru melalui komunikasi.

Pendapat Stella Ting-Toomey senada dengan pendapat Samovar, dkk (2009) yang menyatakan definisi komunikasi antar budaya sebagai interaksi antar individu-individu yang memiliki pengetahuan budaya dan sistem simbol kebudayaan yang berbeda untuk mengubah kegiatan komunikasi.

Triandis dalam Samovar, Porter, \& McDaniel (2009: 23) mendefinisikan budaya sebagai hasil ciptaan manusia, yang elemen-elemen objektif dan subjektifnya berasal dari masa lalu atau turuntemurun. Elemen-elemen tersebut pada akhirnya disosialisasikan pada aspek kehidupan sehari-hari dan dapat digunakan untuk memenuhi partisipanpartisipan (masyarakat setempat) dalam lingkungan sosial. Aspek-aspek kehidupan berbudaya dikomunikasikan pada masyarakat yang memiliki bahasa yang sama dan hidup di waktu dan tempat yang sama.

Beberpa ahli budaya telah mengambil fokus yang berbeda untuk mengulas lebih dalam mengenai 
komunikasi lintas budaya. Edwart T. Hall (1976) menyebutkan adanya dua konteks dalam budaya yang dinamai sebagai budaya konteks rendah dan budaya konteks tingggi. Yang dimaksud sebagai budaya konteks budaya rendah adalah keterbukaan informasi dalam berkomunikasi atau blak-blakan. Sedangkan budaya konteks tinggi lebih tertutup dalam berbagi informasi atau berkomunikasi.

Holliday, Hyde, \& Kullman (2004: 64) mengambil sisi pemahaman budaya yang berbeda. Menurut Holliday, budaya dibagi menjadi budaya kecil dan budaya besar. Budaya kecil merupakan kelompok-kelompok sosial yang ada dalam masyarakat, sedangkan budaya besar sudah mencakup etnisitas nasional ataupun internasional. Budaya kecil ini mengacu pada komposit perilaku kohesif yang dinamis dalam kelompok sosial. Budaya kecil akan bersifat dinamis dibandingkan dengan perbedaan etnis secara global.

Aspek penting lainnya dalam kajian komnunikasi lintas budaya adalah bahasa. Gudykunst (1988: 01) menyebutkan jika bahasa tidak akan dapat 
dipisahkan dari budaya. Bahasa digunakan oleh tiap individu untuk mengetahui mana kelompoknya dan mana kelompok orang lain. Oleh karena itu, budaya adalah sesuatu yang tepat untuk menentukan identitas sosial seseorang. Bahasa Jawa, Sunda, Madura, dan lainnya merupakan contoh dari identitas sosial tersebut.

Istilah yang seringkali dilekatakan pada perbedaan identitas di atas adalah munculnya pemahaman tentang kelompok kita (in group) dan kelompok mereka (out group). Hal ini berpengaruh pada tingkat kolektivitas dan kedekatan komunikasi antar individu yang ada dalam satu kelompok, dibandingkan dengan kolektivitas dan keterbukaan komunikasi individu dengan kelompok lain.

Untuk menggabarkan fenomena kelompok budaya di atas Samovar, Porter, \& McDaniel (2009) menyampaikan sebuah pepetah bahwa individu dalam keluarga, yang dalam ini adalah satu kelompok sosialbudaya merupakan satu-kesatuan yang tidak akan dapat dipisahkan ibarat jari dan tangan. 


\section{B. Fungsi Komunikasi Lintas Budaya}

Samovar, Porter, \& McDaniel (2009) menyatakan fungsi komunikasi dalam komunikasi lintas ataupun antar budaya sebagai berikut: (1) mendapat pengetahuan yang luas mengenai komunikan, yang mencakup dari keseluruhan latar belakang sosial-budaya, (2) memenuhi kebutuhan tiap individu, (3) membentuk identitas pribadi, dan (4) mempengaruhi sikap dan tindakan orang lain.

Hal yang pertama kali dilakukan oleh seorang komunikator ketika bertemu dengan komunikan adalah mencari informasi mengenai diri komunikan. Dalam hal ini pengalaman dari komunikator akan bermain dan menentukan sikap apa yang dipilih ketika nantinya menjalin komunikasi.

Proses adaptasi di atas dilakukan untuk samasama memenuhi kebutuhan pribadi. Umumnya, seseorang akan mencoba untuk merasa senang, nyaman, dan terhibur saat melakukan berkomunikasi. Komunikasi tidak hanya berguna untuk mendapatkan informasi dan memenuhi kebutuhan pribadi, namun juga berperan dalam menentukan dan mendefinisikan 
identitas sosial, apakah menjadi seorang pemuka agama, tokoh masyarakat, atau yang lainnya. Disamping itu, komunikasi juga dapat digunakan untuk mempengaruhi, dan merubah perilaku orang lain.

Rangakain komunikasi di atas akan berlangsung secara dinamis. Saling mempengaruhi di antara komunikator dan komunikan, membuat komunikasi menjadi dua arah, dimana keduanya saling menyusun pesan dan memberikan timbal balik agar dapat menanamkan pengaruh dan tujuan dari komunikasi yang dilakukan.

Menurut Parkers, Laungani, dan Young (dalam Samovar, Porter, dan McDaniel, 2009) menyatakan bahwa semua proses budaya dominan dari sebuah komunitas budaya diorganisasikan oleh agama, di mana lebih ditonjolkan pada keyakinan dan tata cara hidup beragama, ritual, tabu, dan upacara-upacara. Hal tersebut menjadi identitas budaya yang memiliki fungsi sebagai kontrol sosial, penyelesaian konflik, penguatan solidaritas kelompok, referensi, dan dukungan emosional. 
Unsur budaya lainnya adalah nilai-nilai yang dianut. Samovar, Porter, dan McDaniel (2009) menyebutkan bahwa budaya terikat dengan nilai-nilai yang telah dibuat. Nilai-nilai tersebut lebih dikenal dengan sistem norma dan kepercayaan. Nilai-nilai ini bersifat obyektif bagi anggota suatau budaya saja, dan dengan demikian tingkat kebenarannya akan berbeda dengan nilai-nilai dari budaya lain.

Selain agama dan norma, ada pula organisasiorganisasi sosial dalam komunikasi lintas budaya. Samovar, Porter, dan McDaniel (2009: 26) menyebut organisasi ini sebagai sistem sosial dan atau struktur sosial yang membawahi berbagai unit sosial yang terkandung dalam budaya. Kemudian unsur budaya yang terakhir adalah bahasa. Bahasa merupakan fitur umum yang ada dalam semua budaya.

Unsur-unsur di atas melambangkan identitas dari kebudayaan itu sendiri. Samovar, Porter, \& McDaniel (2009) menyebutkan persepsi dan sikap yang akan muncul pada perbedaan identitas kultural adalah stereotip, prasangka, rasisme, dan etnosentrisme. 
Stereotip adalah persepsi negatif yang sangat berbahaya dalam komunikasi lintas budaya dan antar budaya. Seringkali stereotip bersifat kontraproduktif. Hal ini mengancam keharmonisan antar budaya karena stereotip selalu berisi hal buruk dan itu berlaku umum bagi seluruh anggota budaya.

Lebih bahaya lagi jika stereotip diproduksi oleh tokoh masyarakat dan bahkan media massa sehingga level penyebarannya menjadi lebih masif. Banyak pelabelan buruk terhadap suatu budaya terjadi tanpa adanya konfirmasi dari anggota budaya yang dilabelkan. Umumnya masyarakat hanya taken for granted dengan stereotip jelek budaya lain, dan terinternalisasi dalam dirinya sehingga memperlebar jarak komunikasi antar budaya jika bertemu dengan anggota budaya yang distereotipkan.

Selain stereotip, stigma negatif terhadap budaya lain adalah buruk sangka. Buruk sangka lebih bersifat individual, terjadi karena adanya pengalaman komunikasi yang buruk saat bertemu anggota budaya lain, sehingga berprasangka semua anggota budaya tersebut sama buruknya. 
Perbedaan budaya yang meliputi ras, etnis, agama, suku, agama, dan lainnya berpotensi terhadap prasangka buruk. Ruscher dalam Samovar, Porter, \& McDaniel (2009: 117) menyebutkan dalam ilmu komunikasi, perasaan buruk antar budaya biasa dilakukan oleh individu-individu melalui pelabelan kelompok, humor atau lelucon, dan pidato atau pernyataan atas keunggulan kelompoknya dibandingkan dengan kelompok yang lain.

Pada akhirnya prasangka akan menimbulkan kebenciaan yang tidak berdasar antar budaya. Jika kebencian ini berlaku secara masif, pelabelan buruk tersebut akan terjadi secara turun-temurun melalui budaya tutur masyarakat budaya. Stereotip dan prasangka rawan digunakan secara sengaja untuk kepentingan politik atau lainnya untuk menyudutkan kebudayaan ataupun kelompok lain.

Kemudian yang ketiga tindakan rasis. Rasisme berbicara mengenai perbedaan ras yang dapat menimbulkan konflik. Kebanggaan pada ras sendiri dan benci terhadap ras lainnya merupakan aspek yang dapat menimbulkan konflik antar budaya. 
Terakhir adalah etnosentrisme. Etnosentrisme adalah pandangan yang meninggikan budaya dan etnis sendiri sehingga menganggap budaya lain lebih rendah. Adler dan Proctor (dalam Samovar, 2009: 15) menjelaskan fungsi komunikasi dengan cara berikut: "Selain memuaskan kebutuhan sosial dan membentuk identitas, komunikasi paling sering digunakan untuk memuaskan tujuan komunikasi opinion leader: mempengaruhi orang lain untuk bertindak sesuai yang diinginkan.

Semakin etnosentris seseorang atau kelompok budaya, maka akan menimbulkan kecemasan saat terjadi komunikasi lintas dan antar budaya. Masingmasing kelompok budaya tidak berkomunikasi secara tulus, cenderung menutup-nutupi informas, dan saling tidak percaya satu-sama lain.

\section{Ringkasan}

Komunikasi lintas budaya terfokus pada interaksi antar individu yang berbeda latar belakang sosial budaya. Perbedaan tersebut meliputi keyakinan, nilai-nilai, bahasa, dan persepsi dari tiap komunitas kebudayaan. Karenanya, dengan mempelajari 
komunikasi lintas budaya, individu dapat mengetahui langkah-langkah adaptif yang harus diambil ketika bertemu dengan individu dari lingkungan budaya yang lain. Hal ini dapat menghindarkan persepsi-persepsi negatif antar kebudayaan seperti: stereotipe, prasangka buruk, rasisme, dan etnosentrisme ketika berkomunikasi lintas budaya.

\section{Pertanyaan Evaluasi dan Diskusi}

1. Sebutkan pengertian komunikasi lintas budaya menurut Stella Ting-Toomey dan contohnya?

2. Jelaskan apa saja unsur budaya yang berpengaruh pada komunikasi lintas budaya?

3. Jelaskan apa saja sikap negatif yang perlu kita hindari saat terjadi komunikasi lintas budaya?

4. Diskusikan dengan 1 teman anda bagaimana cara kita menangani sikap-sikap negatif dalam komunikasi lintas budaya agar tidak terjadi konflik? 


\section{Referensi}

Gudykunst, William B. (1988). Language and Ethnic Identity. Philadelpia: MULTILINGUAL MATTERS LTD.

Hall, Edward, T. (1976). Beyond Culture. New York: Doubleday.

Holliday, Adrian, Hyde, Martian, \& Kullman, John. (2004). Intercultural Communication. London: Routledge.

Samovar, Larry, A., Porter, Richard, E., \& McDaniel, Edwin, R. (2009). Communication Between Cultures. Boston: Wadsworth.

Purwasito, Andrik. (2003). Komunikasi Multikultural.

Surakarta: Muhammadiyah University Press.

Ting-Toomey, Stella. (1999). Communicating Across

Culture. New York: The Guildford Press. 


\section{BAB 2 \\ INTERAKSIONISME SIMBOLIK}

\section{Tujuan Instruksional Umum}

Setelah menyelesaikan Bab 2 mahasiswa diharapkan mampu:

1. Memahami teori interaksionisme simbolik.

2. Memahami hubungan interaksionisme simbolik dengan kajian komunikasi lintas budaya.

\section{Tujuan Instruksional Khusus}

Setelah mempelajari dan mengerjakan evaluasi di akhir Bab 2 ini mahasiswa diharpkan mampu:

1. Menjelaskan pengertian teori interaksionisme simbolik.

2. Menjelaskan hubugan teori interaksionisme simbolik dengan kajian komunikasi lintas budaya. 


\section{A. Definisi Interaksionisme Simbolik}

Dharma (2018) menyebutkan hal terpenting yang hendaknya dilakukan pertama kali ketika berinteraksi dengan orang dari kebudayaan lain adalah beradaptasi. Adaptasi yang dimaksud ialah menyesuaikan diri dengan umpan balik yang diberikan oleh orang lain.

Transaksi komunikasi (dalam bentuk apapun) sejatinya menekankan pada komunikasi interpersonal itu sendiri dan peran ganda asumsi seseorang saat berkomunikasi, atau dengan kata lain terjadi saling persesi saat transaksi komunikasi terjadi (Wood, 2010: 18).

Dengan demikian, transaksi komunikasi lintas budaya bersifat dinamis dari waktu ke waktu. Perubahan dinamika tersebut disebabkan adanya perubahan pengalaman seseorang saat berinteraksi dan bertemu dengan orang yang baru seperti penjelasan dalam gambar berikut: 


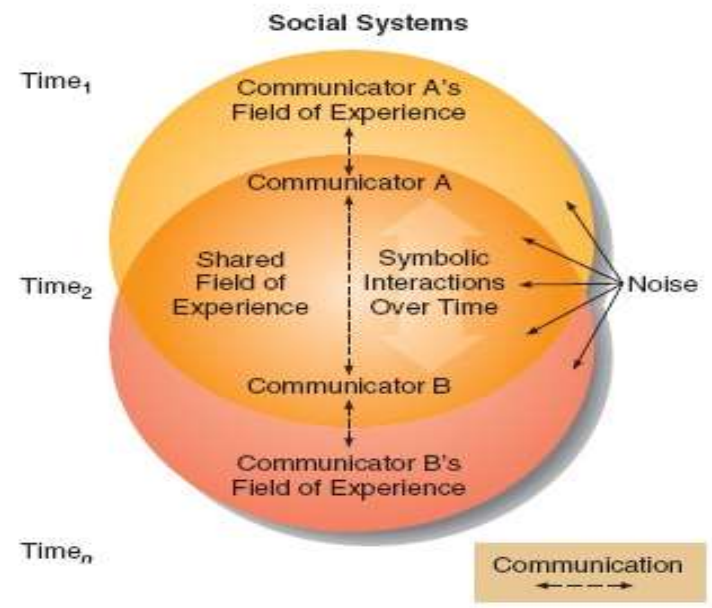

Model Transaksi Informasi Julia T. Wood (2010: 18)

Model yang digambarkan oleh Wood di atas menunjukkan bahwa pengalaman berkomunikasi sangat menentukan masa depan sebuah hubungan. Pasangan komunikasi dapat bertukar pengalaman komunikasinya untuk membentuk, menjaga, dan mengembangkan hubungan yang baik di antara mereka.

Dari gambar di atas jelas terlihat bahwa ada sumber ganguan pada semua aspek transaksi informasi yang berpotensi merusak hubungan komunikasi. Oleh karena itu, perlu adanya kesadaran bagi komunikator/an agar terus belajar dari 
pengalamannya saat melakukan komunikasi dengan orang yang berbeda demi terciptanya hubungan yang romantis. Wood menyatakan bahwa:

"The meanings we assign to behavior in romantic relationships are not entirely individualistic. They also reflect broad cultural views, which we learn and often internalize. For this reason, there are strong consistencies in how people socialized in the same culture and social groups attribute meaning to communication in romantic relationships." (Wood, 2010: 282).

Sering kali tindakan komunikasi seseorang merupakan internalisasi ataupun cerminan dari kebudayaan yang luas. Artinya, ada peluang untuk meginternalisasi individu dalam budaya yang sama, kelompok sosial, hingga budaya lain agar tercipta hubungan yang harmonis. Konsistensi dan strategi sosialisasi tersebut hendaknya telah dipertimbangkan secara matang karena perilaku romantis saat berkomunikasi adalah aspek yang penting dalam mewujudkan hubungan yang romantis.

Hartley (1999: 111-112) menyebutkan bahwa ada kalanya seseorang memiliki harapan agar orang lain berperilaku sesuai dengan apa yang diharapkan. 
Oleh karena itu, seseorang akan menggunakan caracara tertentu untuk mendapatkan sikap dan perilaku orang lain sesuai dengan apa yang diharapkan. Di sini lah interaksi simbolik akan berperan. Seseorang dapat memainkan simbol-simbol dalam transaksi komunikasi agar hubungan yang terjalin menjadi harmonis.

Interaksi simbolik dinyatakan dalam sebuah percakapan yang mengacu pada karakter tertentu dan yang khas dari interaksi manusia. Kekhasan yang terdiri dalam kenyataan bahwa manusia menginterpretasikan atau mendefinisikan tindakan masing-masing, bukan hanya bereaksi terhadap tindakan tersebut. Pemaknaan atau interpretasi tersebut tentu saja melibatkan stimulus dan respon (Blumer, 1969: 78-79).

Saling persepsi antar komunikator/an sangat lazim terjadi pada sebuah interaksi sosial. Pada hakikatnya, selain sebagai makhluk sosial, manusia juga makhluk yang berpikir, dan akan selalu memroses segala rangsangan atau stimulus yang diberikan. Stimulus tersebut dapat berupa suara dan pengalaman interaksi sehari-hari. Dalam hal ini Mead 
(1934: 173-174) telah membahas fondasi sosial dalam diri seseorang untuk merespon perkataan orang lain. Mead secara eksplisit menelusuri konsep "I" dan "Me". Konsep ini ingin menunjukkan bahwa manusia tidak bisa lepas dari penilaian orang lain. Konsep diri kita dipandang sebagai subjek "I" yang berpikir dan menilai, sedangkan di pihak lain, kita sekaligus menjadi objek "Me" yang dipandang dan dinilai oleh orang lain. Tidak hanya melalui diri sendiri ataupun orang lain secara individual, pandangan dan penilaian terhadap diri sendiri pun juga dapat dianalisis melalui masyarakat. Masyarakat sebagai sebuah efek dari aktivitas sosialisasi antar individu, merujuk pada adanya hasil ekspektasi yang kemudian dimunculkan dalam interaksi sosial.

Konsepsi dari interaksi simbolik sendiri menekankan bahwa idividu ataupun sekelompok masyarakat memiliki hasrat subyektif untuk terlihat lebih baik dari yang lain. Kendati demikian, simbolsimbol yang dikomunikasikan dapat dikonstruksi untuk tujuan yang baik demi keutuhan suatu hubungan yang telah terjalin. 
Dalam pandangan interaksi simbolik, makna muncul melalui interaksi yang melibatkan konsep diri seseorang (Littlejohn \& Foss, 2011). Konsep diri adalah obyek sosial penting yang melibatkan rencana tindakan dalam diri individu, identitas individu, ketertarikan, kebencian, tujuan, ideologi, serta evaluasi diri.

\section{Ringkasan}

Interaksi simbolik adalah proses manusia menempatkan diri di lingkungan sosial. Tiap individu berupaya mengenal siapa dirinya melalui aksi dan respon saat berinteraksi dengan masyarakat. Individu akan berinteraksi dengan dirinya sendiri sebelum memutuskan bagaimana akan bertingkah laku terhadap suatu obyek sosial. Sebagai contoh, seorang anak kecil akan memahami posisinya jika berinteraksi dengan orang yang lebih tua. 


\section{Pertanyaan Evaluasi dan Diskusi}

1. Sebutkan apa yang dimaksud dengan konsep "I" dan "Me" saat seseorang sendang berkomunikasi?

2. Diskusikan dengan teman anda mengenai contohcontoh interaksi simbolik dalam kehidupan sosialbudaya?

\section{Referensi}

Blumer, H. (1969). Symbolic Interactionism: Perspective and Method. London: University of California Press, Ltd.

Dharma, F. A. (2019). Managing Intercultural Interaction And Prejudice Of The Indonesian Community: As an Effort To Prevent And Manage Sara Conflict. INFORMASI: Kajian Ilmu Komunikasi, 48 (2), Pp. 281-293. doi: http://dx.doi.org/10.21831/informasi.v48i2.22961.

Hartley, Peter. (1999). Interpersonal Communication: Second Edition. New York: Routledge.

Littlejohn, Stephen W., dan Foss K. A. (2011). Theories of Human Communication. Tenth Edition. Albuquerque. New Mexico: Wadsworth Publishing Company. 
Mead, George, H. (1934). Mind, Self, and Society: From The Standpoint of a Social Behaviorist. Edited and with an introduction by Charles W. Morris. Chicago: THE UNIVERSITY OF CHICAGO PRESS.

Wood, T. Julia. (2010). Interpersonal Communication: Everyday Encounters, Sixth Edition. Boston: Wadsworth. 


\section{BAB 3}

\section{AKULTURASI DAN SISTEM KEBUDAYAAN}

\section{Tujuan Instruksional Umum}

Setelah menyelesaikan Bab 3 mahasiswa diharapkan mampu:

1. Memahami pengertian akulturasi.

2. Memahami sistem-sistem budaya yang ada di masyarakat.

\section{Tujuan Instruksional Khusus}

Setelah mempelajari dan mengerjakan evaluasi di akhir Bab 3 ini mahasiswa diharpkan mampu:

1. Menjelaskan pengertian akulturasi.

2. Menjelaskan sistem-sistem kebudayaan yang ada di masyarakat beserta contoh konkritnya. 


\section{A. Akulturasi}

Secara terminologi akulturasi berasal dari bahasa Inggris yakni acculturation. Menurut Koentjaraningrat (1990) akulturasi merujuk pada proses sosial jika terdapat sekolompok budaya yang melakukan kontak dengan nilai-nilai atau elemenelemen atau sistem kebudayaan lain. Sebagai akibatnya unsur unsur kebudayaan asing tersebut diterima oleh individu dan diolah ke dalam kebudayaan sendiri. Akan tetapi proses sosial ini tidak menghilangkan kepribadian kebudayaan asli.

Raymond Williams menyebutkan ciri keseharian kebudayaan sebagai "keseluruhan cara hidup". Williams konsen pada pengalaman kelas pekerja dan bagaiman mereka secara aktif mengkonstruksi kebudayaan sendiri. Hal ini berhubungan dengan sistem politik yang menekankan demokrasi, pendidikan, dan revolusi jangka panjang (Barker, 2015: 39). Manusia hidup dalam sebuah komunitas yang memiliki kebijakan tentang cara hidup komunal, dan komunikasi adalah satu-satunya jalan untuk mencapai konsensus. 
Merujuk pada penjelasan di Bab. 1, tiap masyarakat sejatinya memiliki kebudayaan yang telah ada sejak dahulu dan diwariskan secara turuntemurun. Karenanya, penting pada bab ini untuk mengetahui apa saja sistem kebudayaan yanng ada di masyarakat.

\section{B. Sistem Kebudayaan}

Liliweri (2009) nmenyebutkan 7 (tujuh) sistem kebudayaan yang ada dalam masyarakat, yakni: (1) sistem ekonomi, (2) sistem keluarga, (3) sistem politik, (4) sistem kontrol sosial, (5) sistem manajemen kesehatan, (6) sistem pendidikan, (7) sistem religi. Semua sistem kebudayaan tersebut berada pada situasi komunikasi antar budaya dan menjadi obyek akulturasi tiap individu ataupun masyarakat.

1. Sistem Ekonomi. Sistem ini didefinisikan sebagai aktivitas pengolahan sumberdaya alam, tenaga kerja, teknologi, produksi dan distribusi barang/jasa atau struktur pelayanan yang dilakukan secara berulang-ulang dan teratur. Menurut Liliwer (2009) ada 3 (tiga) bentuk 
pertukaran barang dan jasa yang dilakukan oleh masyarakat yang berbudaya, yakni:

a. Pertukaran timbal balik: tidak didasarkan pada perjanjian, ikatan atau sanksi. Contohnya adalah kearifan lokal masyarakat Jawa Pedesaan yang menyediakan air dalam kendi di depan rumah. Siapapun yang haus diperbolehkan minum tanpa syarat.

b. Pola pertukaran secara adil: yakni pertukaran secara adil berdasarkan perdagangan secara tertutup. Contohnya suatu suku yang memisahkan kegiatan ekonomi dari aspek geografis. Orang yang tinggal di pegunungan menghasilkan padi, jagung sedangkan orang yang tinggal di pesisir menagkap ikan kemudian hasilnya ditukar.

c. Pola pertukaran atas asas pasar: adanya permintaan dan penawaran. Pola ini dilakukan oleh masyarakat moderen yang bergantung pada nilai tukar (uang).

2. Sistem Keluarga. Nilai-nilai dasar tentang kebenaran dan keadilan, kebaikan dan kejahatan, adat istiadat dan ritual yang disosialisasikan 
melalui keluarga. Setiap suku dan kebudayaan mengenal istilah keluarga yang meniscayakan adanya in-group dan out-group. Lebih dari itu, ada kelompok masyarakat yang hanya mengakui keluarga inti dan juga ada kelompok yang mkengakui adanya marga atau nasab. Hal ini nantinya juga akan berpengaruh pada sistem perkawinan dan sosial.

3. Sistem Politik. Elman (1962) dalam Liliweri (2009) mengelompokkan organisasi sosial dan politik dalam kebudayaan menjadi 4 tipe: (1) band, atau kelompok sosial yang tidak memiliki tempat tinggal tetap; (2) tribe, suatu kelompok yang memiliki kesadaran akan kebudayaan yang sama; (3) chiefdom, suatu bentuk organisasi sosial-politik yang beada di antara tribe dan state; (4) state, bentuk organisasi sosial-politik yang didasarkan pada pemerintahan terpusat dan stratifikasi ekonomi.

4. Sistem Kontrol Sosial. Proses yang terencana atau tidak yang bertujuan untuk mengajak, mendidik atau bahkan memerintahkan warga masyarakat agar mematuhi norma dan nilai. Maka 
dari itu ada kontrol sosial yang formal dan informal.

5. Sistem Manajemen Kesehatan. Mengacu pada topik-topik tentang evolusi, adaptasi (psikologis), anatomi komparatif, tipe-tipe ras, genetika dan serologi. Juga memperhatikan etnogrfi tradisional seperti pengobatan primitif, termasuk sihir dan magis.

6. Sistem Pendidikan. Pendidikan dapat diartikan sebagai proses sosialisasi nilai dan norma serta perilaku dari suatu generasi ke generasi yang lain.

7. Sistem Agama. Substansi agama diidentikkan dengan seperangkat simbol kebudayaan dan gagasan yang memusatkan perhatian dan memberikan makna pada kehidupan manusia dan alam yang tidak diketahui. Semua kebudayaan mengajarkan bagaimana mengenal Tuhan dan segala yang metafisik tentang alam semesta.

Ketujuh sistem kebudayaan di atas ada pada sistem pengetahuan lokal masyarakat. Liliweri (2014: 222) menyebutkan jika pengetahuan ini berhubungan dengan praktek hidup masyarakat yang dikembangkan atas dasar pengalaman sejarah yang sudah 
membudaya dengan lingkungan alamnya. Hal ini menjadikannya suatu identitas budaya. Contohnya Komunitas Ihamahu/Maluku yang diperkenankan menebang satu pohon sagu namun hartus menggantinya dengan menanam 10 anakan sagu.

Marrewijk (1998) dalam Liliweri (2014) menyebut kearifan lokal sebagai keseluruhan pengetahuan dan keterampilan masyarakat lokal yang membuat mereka mampu mendapatkan sesuatu dari lingkungan alam. Ada komponen kepercayaan dan keyakinan yang mengatur peranan mereka dalam ekosistem dan bagaimana mereka berinteraksi dengan alam. Pengatahuan ini lebih dikenal folklore karena diwriskan secara lisan, bukan tulisan, misalnya ada dalam lagu tradisional, cerita rakyat, legenda, mitos, dongeng, dan juga diawetkan dalam artefak-artefak budaya.

\section{Contoh Fenomena}

Konsep Lingkungan dan Hutan Suku Dayak. Mudiyono (1995) dalam Liliweri (2004) menjelaskan bahwa system perladangan Suku Dayak didasarkan pada pengetahuan tentang bintang tujuh. Apabila 
bintang tujuh tekah muncul dan malam hari udara dingin, maka sudah saatnya besok pagi mereka membuak ladang. Apabila bintang tujuh berada di Timur, sedangkan bintang satu lebih rendah, maka orang sudah boleh menanam padi. Jika langit tampak garis seperti tembok dan awan menyerupai sisik ikan, maka musim kemarau telah tiba. Sebaliknya, jika pagi hari langit tampak merah dan awan menggumpal seperti gunung, maka musim penghujan segera tiba.

Apabila akan membuat bahan-bahan rumah, hendaknya tidak menebang pohon kayu dan bamboo pada waktu bulan sedang membesar. Jika melanggar maka kayu-kayu itu akan cepat dimakan bubuk. Kemudian, untuk memastikan kesuburan tanah, orang Dayak melihat pohon-pohon yang tumbuh. Jika terdapat pohon-pohon kayu besar dan tinggi, maka humusnya sangat subur, karena sudah lama tidak diladangi. Untuk menambah keyakinannya, mereka menusukkan ujung parang kira-kira $10 \mathrm{~cm}$. tanah berwarna kehitam-hitaman yang melekat di sisi-sisi parang akan menunjukkan kesuburannya.

Sistem cocok tanam mereka adalah system rotasi dan masa bero panjang. Namun kini telah 
digantikan oleh pemerintah yang lebih percaya pada system modern karena system perladangan Suku Dayak dianggap buang waktu dan tidak menjanjikan apapun (Dove, 1994; Liliweri, 2014). Suku dayak selalu mengusahakan tanaman perkebunan mereka menyerupai hutan, seperti karet, rotan, tengkawang, karena hutan dan Suku Dayak telah akrab sejak berabad-abad lamanya.

\section{Ringkasan}

Akulturasi adalah bertemunya individu atau kelompok masyarakat dengan kebudayaan asing. Pertemuan ini mengakibatkan terjadinya adobsi kebudayaan asing, meskipun tidak meninggalkan kepribadian kebudayaan orisinil mereka. Dalam hal ini terdapat 7 (tujuh) sistem kebudayaan, yakni: (1) ekonomi, (2) keluarga, (3) politik, (4) kontrol sosial, (5) manajemen kesehatan, (6) pendidikan, (7) religi, yang kesemunaya itu disebut sebagai pengetahuan tradisional atau kearifan lokal. 


\section{Pertanyaan Evaluasi dan Diskusi}

1. Sebutkan apa yang dimaksud dengan akulturasi budaya?

2. Diskusikan dengan teman anda mengenai contohcontoh dari 7 sistem kebudayaan yang ada di daerah anda.

\section{Referensi}

Barker, Chris. (2015). Cultural Studies: Teori dan

Praktek. Terj.: Nurhadi. Yogyakarta: Kreasi Wacana.

Koentjaraningrat. (1990). Sejarah Teori Antropologi

II. Jakarta: Universitas Indonesia.

Liliweri, Alo. (2009). Dasar-dasar Komunikasi Antar Budaya. Yogyakarta: Pustaka Pelajar.

Liliweri, Alo. (2014). Pengantar Studi Kebudayaan.

Bandung: Penerbit Nusa Media. 


\section{BAB 4}

\section{KAJIAN TENTANG FOLKLORE NUSANTARA}

\section{Tujuan Instruksional Umum}

Setelah menyelesaikan Bab 4 mahasiswa diharapkan mampu:

1. Memahami definisi folklor dan perkembangannya di era sekarang.

2. Memahami bentuk ataupun jenis folklor.

3. Memahami realitas dan komodifikasi pada folklor.

\section{Tujuan Instruksional Khusus}

Setelah mempelajari dan mengerjakan evaluasi di akhir Bab 4 ini mahasiswa diharpkan mampu:

1. Menjelaskan pengertian foklor dan perkembangannya di era sekarang.

2. Menjelaskan bentuk-bentuk dan jenis folklor yang ada di masyarakat.

3. Menjelaskan realitas dalam folklor dan bentuk komodifikasi folklor di era sekarang. 


\section{A. Definisi Umum Folklor}

Folklor adalah kata serapan dari folklore yang berasal dari duu kata, yakni folk dan lore. Folk diartikan sebagai kolektif, yang mana dijelaskan sebagai ciri-ciri pengenal fisik, sosial, dan kebudayaan yang dimiliki oleh sekelompok orang. Sedangkan lore merupakan tradisi dari folk, yakni kebudayaannya, yang diwariskan secara turun-temurun melalui lisan atau suatu komunikasi nonverbal seperti sebuah contoh yang disertai dengan gerka isyarat atau alat bantu pengingat. Secara keseluruhan folklor adalah sebagian kebudayaan suatu kelompok orang yang disebarluaskan dan diwariskan secara turun-temurun dalam bentuk lisan maupun contoh yang disertai dengan gerak isyarat alat pembantu pengingat (Alan Dundes dalam Danandjaya, 1997:1).

Agar dapat membedakan folklor dengan atau dari produk-produk kebudayaan lainnya, maka penting untuk mengetahui ciri-ciri penganal utama atau yang khas dari folklore. Danandjaya (1997: 3) secara khusus telah merumuskan ciri-ciri folklor sebagai berikut: 
1. Penyebaran dan pewarisannya biasanya dilakukan secra lisan, yakni disebarkan melalui turu kata dari mulut ke mulut.

2. Folklor bersifat tradisional, yakni penyebarannya dalam bentuk yang relative statis atau standar. Disebarkan di antara kelompok orang tertentu paling sedikit dua generasi.

3. Folklor ada (exist) dalam berbagai versi bahkam varian-varian yang berbeda. Hal ini disebabkan oleh cara penyebaran melalui lisan, sehingga sangat rentan terhadap interpolasi atau sifat lupa diri dari manusia. Kendati demikian, interpolasi hanya akan ada pada luanrannya saja, sedangkan bentuk dasarnya tetap bertahan.

4. Folklor biasanya anonym, di mana penciptanya sudah tidak dapat diketahui lagi.

5. Folklor biasanya memiliki rumus atau berpola. Misalnya cerita rakyat yang sering menggunakan kata-kata klise.

6. Folklor memiliki nilai guna dalam kehidupan bersama suatu kolektif orang. Misalnya cerita rakyat yang memiliki nilai-nilai pendidikan, menghibur, protes sosial, dan proyeksi dari 
keinginan yang terpendam. Menurut William R. Bascom dalam Danandjaya (1997: 19) setidaknya folklor memiliki empat fungsi, yakni: (a) sebagai sistem proyeksi atau cerminan angan-angan suatu kolektif, (b) sebagai alat legitimasi pranatapranata dan lembaga-lembaga kebudayaan, (c) sebagai alat pendidikan anak, dan (d) sebagai alat pemaksa dan pengawas agar norma-norma masyarakat selalu dipatuhi oleh seluruh anggota masyarakat.

7. Folklor bersifat pralogis, yakni mempunyai logika sendiri yang tidak sesuai dengan logika umum.

8. Folklor menjadi milik bersama dari suatu kelompok tertentu. Hal ini disebabkan oleh penciptanya yang anonim, sehingga kelompok tersebut merasa sebagai pemiliknya.

9. Folklor umumnya bersifat polos dan lugu sehingga sering terlihat kasar dan spontan. Hal ini dapat dimengerti karena adanya manifestasi emosi manusia yang jujur. 


\section{B. Unsur dalam Folklor}

Danandjaya (1997: 21-22) menyebutkan jika kebudayaan memiliki tujuh unsur kebudayaan universal; (1) sistem mata pencaharian (ekonomi), (2) sistem peralatan dan perlengkapan hidup (teknologi), (3) sistem kemasyarakatan, (4) bahasa, (5) kesenian, (6) sistem pengetahuan, (7) sistem religi, maka folklor menurut Jan Harold Brunvand memiliki tiga unsur, yakni: (1) floklor lisan (verbal folklore), (2) folklore sebagian lisan (partly verbal folklore), dan (3) folklore bukan verbal (non verbal folklore) seperti arsitektur rumah rakyat, pakaian, tarian rakyat, dan lain sebagainya.

Dundes dalam Endraswara (2009: 30) menyebutkan daftar produk kebudayaa sebuah kolektif yang termasuk dalam folklor, yakni: mitos, legenda, dongeng, lelucon, peribahasa, teka-teki, pujipujian atau nyanyian doa, jimat atau guna-guna (kanujela), doa seperti doa sebelum makan, hinaan, jawaban dengan kata-kata, celaan atau ejekan, godaan (teases), minum untuk keselamatan (toasts), serangkaian kata atau kalimat yang sulit diucapkan, bentuk salam, dan ungkapan perpisahan. 
Selain itu Dundes dalam Endraswara (2009) juga menambahkan bentuk folklor yang lain seperti: pakaian rakyat, tarian rakyat, drama rakyat, kesenian rakyat, kepercayaan rakyat, obat-obata rakyat, instrumen atau alat musik rakyat, nyanyian atau lagu rakyat, ungkapan rakyat, tamsilan rakyat (folk simile), folk metaphor, dan nama, seperti juluka atau gelar. Dari bayak genre folklor yang tersebut, yang paling banyak diteliti oleh para ahli adalah folklor lisan berbentuk cerita prosa rakyat (Danandjaya, 1997: 50). Menurut William R. Bascom (1965: 4), cerita prosa rakyat dibagi dalam tiga kelompok besar, yakni: (1) mite atau mitos, (2) legenda, dan (3) dongeng.

Mitos adalah cerita prosa rakyat yang dianggap benar-benar terjadi dan dianggap suci oleh pencerita atau empunya. Tokoh dalam mitos adalah dewa-dewa atau manusia setengah dewa yang setting lokasinya adalah di dunia. Ciri-ciri tersebut mirip dengan legenda, bedanya kalau legenda adalah cerita mengenai manusia super, dan seringkali dibantu oleh makhluk halus atau kekuatan gaib. Waktu terjadinya sebuah legenda belum terlalu lampau dan tentu terjadi di dunia. Sebaliknya, dongeng tidak terikat dengan 
batas waktu dan tempat, namun sama-sama dianggap benar-benar terjadi oleh pemilik cerita.

Cirri-ciri dari cerita prosa rakyat memiliki kemiripan di antara satu dengan yang lain. Oleh karena itu, jika dalam sebuah penelitian ditemukan sebuah cerita prosa rakyat yang hampir memiliki semua ciri tersebut, maka peneliti harus mencari ciriciri mana yang paling dominan dari bentuk cerita yang sedang diteliti.

Selain itu, menurut Danandjaya (1997: 51) penting untuk memperhatikan folk yang memiliki beragam versi cerita. Cerita Adam dan Hawa misalnya, bagi penganut agama Nasrani dan Islam dari folk yang buta huruf, cerita tersebut adalah mite. Namun bagi penganut agama Nasrani dan Islam yang berpendidikan moderen, maka cerita itu dianggap sebagai legenda, atau bahkan dianggap sebagai dongeng belaka. Dengan demikian cerita prosa rakyat juga mempertimbangkan pengetahuan yang dimiliki oleh pemilik folklor dan konsumennya. 


\section{Cerita Rakyat dan Realitas}

Menurut Vladimir Propp (1984: 3), cerita rakyat saat ini telah menjadi fokus kajian yang sangat penting. Tidak ada satu pun dari ilmu yang fokus pada kemanusiaan, baik itu etnografi, sejarah, linguistic, maupun sejarah sastra, dapat dilakukan tanpa adanya ceirta rakyat. Disamping itu cerita rakyat juga menyadarkan kita bahwa solusi untuk fenomena budaya spiritual yang beragam tersembunyi dalam cerita rakyat, meskipun sampai saat ini cerita rakyat belum menentukan tujuan, materi, atau spesifikasinya sendiri sebagai bidang ilmu pengetahuan.

Cerita rakyat sering diidentikkan dengan karya sastra. Dalam hal ini Popp (1984: 5) menunjukkan salah satu perbedaan paling penting di antara keduanya, bahwa karya sastra selalu memiliki seorang penulis, sedangkan cerita rakyat tidak pernah memiliki seorang penulis, dan ini adalah salah satu fitur khusus mereka.

Para folkloris percaya bahwa kesenian rakyat bukanlah fiksi, bahwa itu benar-benar ada dan studi tentang itu adalah tujuan dasar agar cerita rakyat dianggap sebagai karya folk yang ilmiah. Artinya, 
para folklorist telah berusaha mengembangkan metode ilmiah untuk meneliti folklor, meskipun folklor belum dijadikan sebagai disiplin keilmuan.

Cerita rakyat sangat berkaita dengan identitas sosial-budaya dari folk. Propp (1984: 7) menjelaskan bahwa cerita rakyat adalah sebuah karya yang lahir dari kasus khusus yang mengacu pada sejarah hukum suatu lokus, yang mana bentuk-bentuk produksinya identik dalam budaya material, yang melahirkan institusi sosial identik atau serupa, dengan peralatan budaya serupa, dan mengakar dalam ideologi. Lebih dari itu, cerita rakyat dapat memunculkan kesamaan pemikiran atau cara berpikir, agama, ritual, bahasa, dan legenda. Kesemuanya itu salaing mempengaruhi satu sama lain, dinamis, tumbuh, dan mati.

Cerita rakyat mencerminkan realitas prasejarah, adat istiadat dan moral abad pertengahan, serta hubungan sosial feodalisme dengan kapitalisme (Propp, 1984: 17). Lebih dari itu, terlepas dari distorsi realitasnya, cerita rakyat, dan terutama kisah kehidupan sehari-hari, adalah leluhur dari sastra realistic yang tertulis. Menurut Propp (1984: 49) hubungan cerita rakyat dengan realitas terdiri dari tiga 
jenis, yakni:Cerita rakyat dibuat oleh realitas tetapi tidak mengandung jejak langsung dari realitas konkret atau zaman yang telah melahirkannya. Salah satu contohnya adalah gambar dongeng yang menakjubkan bagi kita, seperti naga api, kuda bersayap, peri, dan lain sebagainya. Contoh tersebut adalah gambar fiktif, namun, monumen yang mengandung gambar seperti itu juga harus dipelajari dan dijelaskan. Penelitian sejarah akan menemukan kapan, di zaman apa, pada tahap mana dari folk, bentukbentuk pemikiran, dan kreativitas artistik, karya-karya dan gagasan-gagasan seperti itu pasti akan muncul.

Jenis relasi cerita rakyat yang kedua dengan realitas mengandaikan plot fiktif yang mengandung jejak hidup orang-orang "yang jelas". Realitas menemukan refleksi meskipun refleksi tersebut bukan merupakan tujuan estetika dari penciptanya. Misalnya, dalam kisah yang mengherankan tentang ibu tiri dan anak tiri, ibu tiri mengirim gadis itu ke monster, yang pasti akan membunuhnya, tetapi ada penolong "berupa binatang buas" yang datang untuk menguji dan memberinya hadiah. Narasi di atas tidak menggambarkan makna yang sesungguhnya, tetapi, 
secara sepintas, kisah itu menggambarkan pondok petani, kehidupan keluarga yang tidak bahagia dari seorang duda yang menikah lagi yang memiliki anakanak dari istri pertamanya.

Dalam kasus ketiga, pencipta bermaksud menggambarkan realitas. Begitulah lagu-lagu tentara tentang daftar catatan, kesulitan pelayanan, penggerebekan, pertempuran, dan kematian dalam pertempuran. Untuk memahami dasar historis dari cerita rakyat, orang harus ingat bahwa cerita rakyat tidak hadir sebagai satu kesatuan yang utuh, bahwa cerita itu terurai menjadi genre. Genre adalah kesatuan utama yang harus dipelajari oleh studi ini. Salah satu ciri dasar genre adalah puisinya: setiap genre memiliki sistem puitis tersendiri. Genre memiliki fitur lain, di mana setiap genre akan memiliki fitur-fitur khusus. Perbedaan dalam perangkat-perangkat puitis tidak hanya memiliki makna formal; mencerminkan adanya perbedaan dengan realitas, dan menentukan berbagai cara untuk mewakilkan realitas dalam bentuk cerita rakyat.

Cerita rakyat memiliki makna psikologis dan budaya karena menjadi urutan ekspresi yang serigkali 
bersifat spontan dan memiliki makna sosial. Dalam narasi tersebut terdapat simbol-simbol yang diuraikan yang juga berisikan pengalaman serta pelepasan kenyataan yang dimanifestasikan ke dalam bentuk ritual. Folklor berbeda dengan dokumentasi historis karena sering berwujud fantasi, tetapi tetap tidak mengurangi kebenaran atau signifikansinya (Dundes, 2007: 3).

Cerita rakyat merupakan subyek yang terdiversifikasi dan kompleks karena mencerminkan mozaik yang rumit dari sisah kebudayaan manusia. Kendati sebagai bagian dari budaya, cerita rakyat lebih sulit dipahami, mengalir bersama secara terpisah dari arus utama pencapaian intelektual umat manusia yang rasional (Brunvand, 1978: 22).

\section{Komodifikasi Folklor}

Di Amerika Serikat, folklor mendapatkan perhatian yang baik oleh pemerintah. Menurut Gillespie (1996: 522) dalam Dharma (2018), pada tahun 1934 pemerintah Amerika telah mengadakan festival folk untuk pertama kalinya. Bagi pemerintah Amerika Serikat, festival tersebut penting diadakan 
untuk menjaga warisan budaya masyarakatnya, bukan pada motif ekonomis dan ideologis.

Gillespie dalam bukunya yang berjudul American Folklore menyebutkan bahwa folklor tidak hanya dihadirkan untuk hiburan semata, oleh karena itu, perhatian audiens bukanlah indeks kesuksesan yang relevan bagi sebuah festival folklore. Fokus yang lebih penting dari adanya festival folklor adalah bagaimana festival tersebut berdampak pada kehidupan partisipannya, bukan hanya berorientasi pada uang yang didapat dan rasa bangga serta validasi seni-budaya mereka (1996: 525).

Sementara itu, David Simpson (2009) menganggap bahwa tanpa disadari tradisi lisan berpotensi dan dapat diubah menjadi suatu komoditas yang layak jual atau dikomodifikasi. Simpson (2009: 7) menyatakan bahwa komodifikasi bukan hanya tentang status objek tertentu dan sikap khusus kita kepada obyek tersebut. Komodifikasi membawa rahasia yang harus dipahami denganbaik. Kita dapat mengetahuinya melalui hubungan barang-barang dan hal-hal di dunia dengan wacana-wacana moral tentang kemewahan dan biayanya. 
Komodifikasi sangat berkaitan dengan kapitalisme. Semua obyek termasuk folklor dapat diubah menjadi sebuah komoditas atau barang dagangan. Komodifikasi sendiri dipahamis ebagai sebuah ruang modofikasi komoditas agar laku di pasaran. Studi budaya sudah cukup lama menggeluti persoalan ini, diantaranya dengan melihat secara kritis proses komodifikasi budaya, di mana industri budaya mengubah orang dan makna menjadi komoditas yang berguna dan bisa dijual. Dalam proses yang disebut Marx sebagai "pemujaan komoditas" (commodity fetishism), penampakan dari barang-barang yang dijual di pasar sebeanarnya menyembunyikan asal usul lahir atau terciptanya barang tersebut yang harus melewati proses eksploitasi pada level produksinya (Piliang, 1999: 61).

\section{E. Folklore dan Pariwisata}

Spillane dalam Sugiyarto dan Amaruli (2018) mendefinisikan pariwisata sebagai suatu perjalanan menuju tempat lain yang bersifat sementara, yang biasanya dilakukan oleh orang-orang yang ingin menyegarkan pikiran setelah sibuk bekerja dan 
memanfaatkan waktu libur dengan menghabiskan waktu bersama keluarga untuk berekreasi. Alasan seseorang berwisata diantaranya dikarenakan adanya dorongan keagamaan seperti berekreasi ke tempattempat suci agama untuk mendalami ilmu tentang agama dan ada juga yang bertujuan untuk berolahraga atau sekedar menonton pertandingan olahraga.

Sementara itu, pengembangan pariwisata menurut (Agusta et. al, 2017: 243) merupakan usaha untuk memanfaatkan daya tarik wisata yang berbentuk indahnya alam, tradisi dan budaya, serta sejarah dan pusaka budaya.

Pariwisata budaya berhubungan erat dengan daya tarik wisata budaya itu sendiri. Penjelasan Rencana Induk Pembangunan Kepariwisataan Nasional (RIPPARNAS) pasal 14 ayat (1) huruf b dalam Wilopo dan Hakim (2017) menjelaskan bahwa daya tarik wisata budaya adalah daya tarik wisata berupa hasil olah cipta, rasa dan karsa manusia sebagai makhluk budaya. Daya tarik wisata budaya dibedakan menjadi dua yaitu daya tarik wisata budaya yang bersifat berwujud (tangible) dan daya tarik 
wisata budaya yang bersifat tidak berwujud (intangible).

Usman Pelly (2015: 147) menunjukkan alasan utama mengapa seseorang mau meningalkan rumahnya, menghasbiskan uang simpanannya untuk berwisata. Oleh karena itu, masyarakat menghindari kekecewaan ketika kunjugan wisata tidak sesuai degan ekspektasi yang diayangkan atau hanya pindah tempat tidur.

Strategi yang tepat menurut Pelly (2015) adalah menciptakan wisata ruang dan waktu: ketika wisatawan membeli souvenir dari para penjual, maka wisatawan terebut ingin ada obyek yang mengingatkan dirinya pada tempat wisata yang pernah dikunjungi. Wisatawan pemborong souvenir ini dalam kepustakaan disebut sebagai "tourism in time", sedang wisatawan yang ingin banyak terliat dalam aktivitas budaya setempat (dari mulai turut serta menari, bernyanyi, mencoba makanan setempat, berbicara dengan penduduk setempat, mendengarkan hikayat, dongeng, kisah tokoh idola setempat, berkeliling melihat panorama alam, berenang, mendayung 
sampan sendiri, mendaki gunung, mengambil foto atau video-kamera).

Penerapan strategi yang jitu agar wisatawan merasa mimpinya telah terpenuhi. Secara psikologis usaha dalam memenuhi mimpi itu dengan cara memberikan rasa "excited", "surprise", tetapi menyejukkan. Walaupu "ritus welcoming" itu tetap dibangun di atas budaya penduduk setempat, tetapi telah dikemas dalam "frame" mimpi wisatawan (Pelly, 2015: 150).

Budaya penduduk dikemas semenarik mungkin agar memiliki nilai jual yang tinggi pada wisatawan. Budaya dikemas dalam pertunjukan (show), berbagai narasi dikemas dan dibumbui dengan pencitraan oleh masyarakat bersama produser (Pelly, 2015: 151). Seperti tari kecak Bali yang telah mengalami beberapa revisi, disesuaikan dengan ruang dan waktu yang up to date. Orang yang datang sepuluh tahun yang lalu mungkin akan terheran jika melihat tari kecak yang sekarang.

Pendekatan pariwisata ini mempromosikan kegiatan pariwisata ramah lingkungan dan keterlibatan masyarakat dalam sektor pariwisata. Namun, eco- 
tourism, entah bagaimana, secara praktis bergantung pada keindahan alam/sumber daya alam sebagai daya tarik wisata utama, sedangkan pengembangan pariwisata berbasis masyarakat tidak selalu menempatkan aspek ekologi sebagai preferensi utama. Poin utamanya adalah apakah dua jenis dari pariwisata tersebut dapat berbagi manfaat bagi orang miskin; dan berapa banyak manfaat yang dapat dirasakan orang miskin secara nyata.

\section{Ringkasan}

Folklor ialah tradisi atau kebudayaan masyarakat yang disampaikan secara turun-menurun melalui lisan. Folklor biasanya berbentuk pepatah daerah, lagu daerah, cerita rakyat, dongeng, dan sejenisnya yang memiliki nilai-nilai pengajaran di dalamnya. Dewasa ini folklor banyak digunakan untuk festivalisasi dan city branding atau mengalami komodifikasi. Banyak desa-desa adat dan festival yang diangkat dari folklor untuk dijadikan sebagai daya tarik pariwisata berbasis budaya dan masyarakat. 


\section{Pertanyaan Evaluasi dan Diskusi}

1. Sebutkan perbedaan folklor dengan sistem kebudayaan?

2. Jelaskan ciri-ciri folklor?

3. Diskusikan dengan teman anda contoh-contoh komodifikasi pada folklor yang ada di Indonesia!

\section{Referensi}

Agusta, Tessaniva., Warto., Supana. (2017). Dampak Komodifikasi Terhadap Perubahan Identitas Tari Topeng Hitam. Haluan Sastra Budaya, 1(1),237252.

Brunvand, John Harold. (1978). The Study of American Folklore: An Introduction, Second Edition. New York: WW Norton \& Company Inc. Danandjaya, James. (1997). FOLKLORE INDONESIA: Ilmu Gosip, Dongeng, dan lainlain. Jakarta: Pustaka Utama Grafiti.

Dharma, F. A. (2018). Komodifikasi Folklor dan Konsumsi Pariwisata di Indonesia. BioKultur, 3 (1), Pp. 1-15. 
Dundes, Alan. (2007). The Meaning of Folklore: The Analytical of Alan Dundes. Edited by: Simon. J. Bronner. Utah: Utah State University Press.

Endraswara, Suwardi. (2009). Metodologi Penelitian Folklor: Konsep, Teori, dan Aplikasi. Yogyakarta: MedPress.

Gillespie, K. Angus. (1996). American Folklore: An Encyclopedia. Edited by John Harold Brunvand. New York \& London: Garland Publishing, Inc.

Pelly, Usman. (2015). Etnisitas dalam Politik Multikultural (Buku 1). Medan: Casa Mesra.

Piliang, A. Yasraf. (1999). Hiperrealitas Kebudayaan. Yogyakarta: LKiS

Propp, Vladimir. (1984). Theory and History of Folklore. Translated by: Ariadna Y. Martin and Richard P. Martin and Several Others. Edited by: Anatoly Liberman. Minneapolis: University of Minnesota Press.

Simpson, David. (2009). Wordsworth, Commodification, and Social Concern: The Poetics of Modernity. Cambridge: Cambridge University Press. 
Wilopo, Khusnul K., Hakim, L. (2017) STRATEGI PENGEMBANGAN DESTINASI PARIWISATA BUDAYA (Studi Kasus pada Kawasan Situs Trowulan sebagai Pariwisata Budaya Unggulan di Kabupaten Mojokerto). Jurnal Administrasi Bisnis, 41(1), 56-65. 


\section{BAB 5}

KOMUNIKASI DAN KENYATAAN

SOSIAL-BUDAYA

\section{Tujuan Instruksional Umum}

Setelah menyelesaikan Bab 5 mahasiswa diharapkan mampu:

1. Memahami hubungan komunikasi dengan kenyataan sosial-budaya.

2. Memahami adanya kenyataan obyektif dan kenyatan subyektif dalam masyarakat.

3. Memahami pembentukan kenyataan melalui teori konvergensi simbolik.

\section{Tujuan Instruksional Khusus}

Setelah mempelajari dan mengerjakan evaluasi di akhir Bab 5 ini mahasiswa diharpkan mampu:

1. Menjelaskan hubungan komunikasi dengan konstruksi sosial-budaya.

2. Menjelaskan bentuk kenyataan obyektif dan kenyataan subyektif.

3. Menjelaskan pembentukan kenyataan melalui teori konvergensi simbolik 


\section{A. Komunikasi Sosial}

Bungin (2014) dalam bukunya berjudul sosiologi komunikasi menyebutkan bahwa proses komunikasi dalam masyarakat berhubungan dengan struktur dan lapisan maupun ragam budaya dan proses-proses sosial yang ada di masyarakat. Dengan asumsi tersebut, maka komunikasi sebagai proses sosial tidak akan lepas dari disiplin sosiologi dan antropologi.

Setiap anggota masyarakat memiliki kesempatan, baik menjadi komunikator maupun komunikan. Kendati demikian, struktur dan lapisan masyarakat bisa jadi membuat sebuah pola komunikasi yang disepakati secara bersama-sama dalam menentukan siapakah yang mendapat porsi dominan sebagai komunikator.

Dengan modal pendidikan, ekonomi, dan sosial, setiap anggota masyarakat akan menggunakan cara-cara berkomunikasi untuk mencapai tujuan, entah dengan menggunakan retorika, koersi, dan cara-cara lainnya. Tujuan komunikasi akhirnya beragam dan tergantung dari apa yang diinginkan oleh komunikator. 
Semua unsur komunikasi diatas saling berhubungan satu sama lain. Penting untuk diperhatikan runag lingkup komunikasinya, yang nantinya akan berhubungan dengan pemilihan media dan produksi pesan yang ingin disampaikan.

Bungin menyatakan, secara umum, proses sosial berbentuk interaksi sosial, sedangkan bentuk khususnya adalah aktivitas-aktivitas sosial dari masyarakat (Bungin, 2014: 55). Dengan demikian, komunikasi sudah jelas berada dalam proses sosial.

Dalam kehidupan sehari-hari, komunikasi akan bersifat dinamis dengan selalu berubah pada aktifitasaktifitas sosial masyarakat. Bungin (2014: 55) menyebutkan dua syarat terjadinya interaksi sosial di masyarakat, yaitu adanya kontak sosial, dan kemudian berlanjut dengan adanya komunikasi.

Kontak sosial erat kaitannya dengan hubungan sosial. Kontak dalam hal ini tidak hanya diartikan sebagai sentuhan secara fisik, namun mengarah pada sentuhan secara sosial. Bungin (2014: 56) menyebutkan 5 bentuk kontak sosial sebagai berikut:

"a. Dalam bentuk sosialisasi yang berlangsung antara pribadi orang per orang. Proses sosialisasi ini memungkinkan 
sesseorang mempelajari norma-norma yang terjadi di masyarakatnya. Berger dan Luckmann (Bungin: 2011: 14), mengatakan proses ini terjadi melalui proses objektivasi, yaitu interaksi sosial yang terjadi dalam dunia intersubjektif yang dilembagakan atau mengalami proses institusional.

b. Antara orang per orang dengan suatu kelompok masyarakat atau sebaliknya.

c. Antara kelompok masyarakat dengan kelompok masyarakat lainnya dalam sebuah komunitas.

d. Antara orang per orang dengan masyarakat global di dunia internasional.

e. Antara orang per orang, kelompok, masyarakat dan dunia global, di mana kontak sosial terjadi secara simultan di antara mereka."

Kemudian aspek kedua adalah komunikasi. Seperti apa yang sudah dijelaskan di atas, bahwa komunikasi tidak hanya dipandang sebagai sebuah interaksi satu arah. Komunikasi, khususnya dalam proses sosial dapat menjadi pemersatu ataupun pemecah hubungan sosial dalam suatu masyarakat.

Hal tersebut erat kaitannya dengan tujuantujuan komunikasi sesorang dalam kehidupan sosial. Gillin dan Gillin dalam Soekanto (2002: 71- 104) dalam (Bungin, 2014: 58) menyebutkan dua bentuk 
proses sosial yang terjadi di masyarakat, yaitu proses sosial asosiatif dan proses sosial disosiatif.

Proses sosial asosiatif berwujud kerja sama antar masyarakat dalam rangka mencapai tujuan bersama. Contohnya adalah ketika kelompok masyarakat saling gotong royong, toleransi, dan bekerja sama dalam kehidupan sehari-hari. Sedangkan proses sosial disosiatif merupakan kebalikan dari proses sosial asosiatif, dimana ada persaingan, tidak ada toleransi, dan akhirnya dapat berbentuk konflik.

Ketika disosiatif ini ditarik pada kehidupan sosial-agama di masyarakat, maka akan dapat menyebabkan permusuhan dan konflik antar umat beragaama. Liliweri (2014: 112) menyebutkan bahwa sistem kepercayaan telah memainkan peranan penting dalam membentuk undang-undang ataupun peraturanperaturan di banyak negara. Jika masyarakat di lingkungannya menerapkan peraturan-peraturan berlandaskan sistem kepercayaan yang mereka anut dan di bumbui proses sosial disosiatif, maka dominasi dan hagemoni sistem kepercayaan dominan akan menindas sistem kepercayaan yang represif. 


\section{B. Realitas Sosial-Budaya}

Lebih jauh lagi Berger dan Luckmann menyebutnya dengan konstruksi sosial. Realitas sosial yang ada di masyarakat ada dalam kehidupan seharihari dan selalu berubah atau dinamis. Realitas sendiri tidak serta merta diterima sebagai hal yang nyata terjadi. Berger dan Luckmann (1966: 13) mengatakan bahwa para filusuf dan para pemikir menenyakan pertanyaan penting mengenai apa itu realitas dan pengetahuan, apa yang nyata? dan bagaimana hal tersebut diketahui?

James W. Carry (2009: 25) menyebutkan bahwa kita tidak dapat memandang komunikasi sebatas representasi dari komunikasi, namun pada representasi untuk komunikasi atau tujuan dari komunikasi. Oleh karena itu, penting dalam sebuah interaksi untuk memerhatikan konstruksi, katakutan, bentuk penggunaan konstruksi realitas, dan ilmu pengetahuan.

Disinilah tujuan dari komunikasi menjadi penting untuk diteliti. Bagaimana seseorang dalam berkomunikasi akan membangun realitas yang dia inginkan agar orang lain percaya bahwa realitas 
tersebut benar adanya. Seperti yang sudah dijelaskan diatas, bahwa dalam rangka mencapai tujuan tersebut, seseorang akan menggunakan media dan lainnya.

Besar kecilnya realitas yang dibangun berbanding lurus dengan tujuan dari komunikasi yang dilakukan. Realitas yang lebih kecil dibangun untuk memengaruhi sedikit orang dan realitas sosial yang lebih besar dibangun untuk pengaruh yang lebih massif, dan bisa jadi menjadi pandangan umum dalam lingkungan sosial.

Dharma (2018) menyebutkan bahwa masyarakat bukanlah entitas obyektif yang berevolusi dengan cara yang ditentukan dan tidak dapat diubah. Manusia selalu menciptakan realitas melalui interaksi sosial yang dinamis. Ketika manusia melakukan kontak sosial dengan orang lain, mereka akan memberikan pesan dan kesan, mendengarkan, mengamati, mengevaluasi, dan menilai situasi berdasarkan cara mereka disosialisaikan untuk memahami dan berinteraksi terhadap diri mereka. Melalui proses pemahaman dan pendefinisian peristiwa yang berlangsung, manusia menafsirkan realitas dan menegosisikan makna. 
Adalah Ernest Bormann, John Cragan, dan Donald Shields yang mengembangkan teori konvergensi menjadi konvergensi simbolis atau Symbolic Convergence Theory (SCT), yang membahas bagiamana individu-individu, dalam kelompok, datang untuk membagi realitas komunikasi. Gambaran mengenai realitas tersebut dipandu oleh cerita-cerita yang menunjukkan bagaimana objek harus dipercaya (Littlejohn, 2011: 206).

Teori konvergensi simbolis komunikasi (Bormann, 1985; Bormann, Cragan, \& Shields, 1994) banyak mewarisi disiplin ilmu akuntansi yang berisikan proses-proses dalam menciptakan dan mempertahankan kelompok atau kesadaran organisasi. Teori konvergensi simbolik (SCT) menyumbang pengembangan visi retoris, simbolik secara umum turut mengambil bagian dalam membuat visi, penciptaan, peningkatan, dan mempertahankan kelompok atau kesadaran masyarakat. Teori ini menempatkan audien di tengah paradigma komunikasi dan menggabungkan semua unsur dari situasi komunikasi termasuk pembicara atau sumber pesan, 
pesan, konteks, dan audien (Bormann, Knutson, Musolf, 1997: 254-255).

Melalui cerita-cerita fiksi ataupun keadaan yang nyata, seseorang dapat mempengaruhi orang lain untuk percaya mengenai cerita yang diberikan. Terlebih jika yang dipengaruhi atau audien memiliki pengetahuan dan kecerdasan dibawah seseorang yang mempengaruhi, maka akan ada kemungkinan ceritacerita tersebut mudah diterima dan dipercaya.

Mitos menurut Cohen (Bolman, 1988; Muhammad, 2005: 62) mempunyai beberapa fungsi, yaitu: untuk menerangkan, menyatakan, menjaga solidaritas dan kesatuan, mitos mengabsahkan, mengkomunikasikan secara tidak sadar keinginankeinginan dan konflik, mitos sebagai penengah dalam pertentangan, dan mitos memberikan cerita waktu yang lalu pada saat sekarang.

Jika funsgi mitos sebagai alat untuk mendapatkan keinginan-keinginan dan konflik dicampur adukkan dalam penyampaian upacara keagamaan, maka akan dapat menimbulkan efek buruk yang sangat besar. Agama menempati sisi kepercayaan yang paling dalam pada pemeluknya, dan 
tentu saja akan mudah memunculkan konflik, mengingat masih banyak masyarakat Indonesia yang percaya pada mitos dan cerita-cerita.

Kendati demikian, merujuk pada penjelasan mengenai mitos diatas, cerita-cerita dapat dirangkai kembali untuk mewujudkan perdamaian. Jalan yang dapat diambil adalah menggunakan pemimpin opini untuk meneruskannya pada masyarakat yang dipimpin.

Perlu diketahui jika fokus utama dari SCT terletak pada hubungan antara pesan yang mendramatisir, rantai fantasi dari berbagai drama, dan grup fantasi yang dihasilkan secara bersama-sama. SCT melingkupi semua konteks komunikasi, di mana komunikator menghasilkan pesan yang dramatis pada audien komunikasi, dalam kondisi yang bagaimana, danketerlibatan audien dalam aksi dramatisasi. Ada beberapa aspek dalam pesan dramatis yang dapat membuat audien menangkap dan memfokuskan perhatiannya pada pesan tersebut hingga audienberimajinasi dan bertindak sesuai dengan rangsangan pesan yang dibuat. Oleh karena itu, konsep utama dari teori ini adalah pesan yamg 
didramatisasi (Bormann, Knutson, Musolf, 1997: 254255).

Formulasi akhir Bormann, dkk terdiri dari empat dimensi dasar: (1) dimensi realitas, (2) dimensi waktu, (3) dimensi moral, dan (4) dimensi emosional.Dimensi realitas dapat dilihat dari baiktidaknya cerita fiktif atau nonfiktif yang dibuat, nyata atau tidak nyata. Ini termasuk dalam kategori yang aneh, kategori fiksi realistis, dan kategori nonfiksi realistis. Bormann, dkk mendefinisikannya sebagai narasi aneh yang berisi mengenai hal-hal yang mustahil, membuat penasaran, aneh, tidak normal, tidak wajar, menyimpang, mengerikan, mistis, dunia lain, luar biasa, ajaib, atau ilusi Bormann, Knutson, Musolf, 1997: 259).

Realitas sendiri dibedakan menjadi dua. Ada realitas fiktif dan realitas nonfiktif. Realitas fiktif sendiri dapat dipahami sebagai realitas semu atau palsu. Ini lebih mirip dengan mitos yang sudah dijelaskan diatas. Sesuai dengan namanya (fiktif), maka realitas ini sengaja diciptakan untuk meyakinkan hal yang sebenarnya tidak nyata adanya. 
Kemudian realitas nonfiktif atau fakta. Realitas ini adalah kenyataan, atau cerita yang benar adanya. Melihat bahwa realitas ini berada dalam kajian konvergensi simbolis, maka realitas juga sengaja diceritakan untuk memberikan pengaruh agar audien atau patisipan komunikasi percaya dan melakukan apa yang diinginkan oleh kounikator.

Cerita-cerita yang diceritakan tidak terlepas dari dimensi waktu. Seperti pada umumnya, dimensi waktu ini dibagi atas masa lalu, masa sekarang, dan masa depan. Masa lalu berisikan cerita-cerita yang ada di masa lalu seperti dongeng, mitos, dan lainnya. Sedangkan masa sekarang adalah apa yang terjadi saat ini, dan masa depan merupakan cerita-cerita yang ditujukan untuk memberi harapan pada audien.

Borman juga membagi dimensi moral. Dimensi moral adalah narasi yang terdiri dari pertanyaan dan jawaban benar-salah, etis dan tidak etis, tepat dan tidak tepat, terhormat dan tidak terhormat, berprinsip dan berprinsip. Dimensi moral termasuk kategori moral sentimental, kategori moral intelektual, dan kategori bermoral. Bormann, dkk mendefinisikan moral-sentimental sebagai dramatisasi 
yang menggambarkan skenario melo, sederhana, dan istilah hitam-putih yang jelas menyatakan nilai-nilai moral yang terlibat. Kemudian moral intelektual terdiri dari cerita yang rumit di mana tokoh protagonis kadang menang dan kadang-kadang kalah. Karakter hidup di dunia yang rumit di mana hal-hal yang tidak pernah hitam dan putih, tidak pernah jelas baik atau jahat. Cerita-cerita dibuat dengan pendekatan etika. Sedangkan kategori bermoral adalah cerita-cerita amoral yang diceritakan secara terpuji dan bermoral (Bormann, Knutson, Musolf, 1997: 260).

Untuk menyebut efek dari cerita-cerita yang disampaikan, Bormann, dkk menyebutknya sebagai dimensi emosional. Dimensi ini meliputi segala perasaan yang ditimbulkan dari cerita-cerita yang sengaja disampaikan, seperti bahagia-sedih, dan lainnya.

Pemimpin opinin dapat menggunakan tindakan persuasif diatas kapanpun dibutuhkan. Sutaryo (2005) menjelaskan bahwa ada tiga alat utama yang dapat digunakan dalam persuasi, yaitu: penalaran dan bukti (evidence), daya tarik pemotivasi, dan daya tarik kredibilitas. 
Vito (dalam Sutaryo, 2005) menyatakan bahwa keberhasilan dalam mengukuhkan, mengubah sikap atau kepercayaan dan mengajak pendengar untuk berbuat sesuatu akan bergantung pada pemanfaatan prinsip-prinsip persuasi berikut: (1) prinsip pemaparan selektif, (2) prinsip partisipasi khalayak, (3) prinsip inokulasi, dan (4) prinsip besaran perubahan.

Pemaparan secara selektif dilakukan karena pemilihan informasi yang tepat menjadi kunci diterimanya informasi dengan baik. Kemudian melihat partisipasi dari orang yang ingin dipersuasi. Jika ditemukan khalayak yang terinkolasi (memiliki argumen-argumen yang menentang), maka dapat digunakan contoh relevan secara halus, dan tidak terlalu kontra dengan pendapat mereka. Tugas dalam melakukan persuasi menjadi sulit tergantung besaran perubahan yang diinginkan. Semakin besar perubahan yang diinginkan dan banyaknya argumen yang kontra akan menjadi tantangan yang sulit. 


\section{Ringkasan}

Komunikasi dan konstruksi realitas sosialbudaya memiliki hubungan yang erat. Sebagai makhluk sosial, manusia tidak akan lepas dari kontak sosial dan budaya. Karenanya, diperlukan pemahaman mengenai konstruksi realitas sosial untuk melihat bagaimana budaya masyarakat dibentuk dan terbentuk sebagai kenyataan obyektif dan kenyataan obyektif. Dalam kenyataan obyektif, manusia adalah produk lingkungan sosial-budayanya, dan dalam kenyataan subyektif manusia adalah organisme yang dapat berpikir dan memiliki kecenderungan tertentu dalam masyarakat. Realitas dapat dibentuk melalui simbol-simbol yang disatukan melalui sebuah cerita rakyat ataupun mitos. Pemersatuan simbol ini disebut sebagai konvergensi simbolik.

\section{Pertanyaan Evaluasi dan Diskusi}

1. Jelaskan hubungan antara komunikasi dan konstruksi sosial-budaya!

2. Jelaskan maksud dari kenyataan obyektif dan kenyataan subyektif! 
3. Diskusikan dengan teman anda bagaimana cara kerja teori konvergensi simbolik dalam membentuk kenyataan.

\section{Referensi}

Berger, L. Peter, \& Luckmann, Thomas. (1966). The Social Construction of Reality. England: Penguin Group.

Bormann, Ernest G. Knutson, Roxann L, Musolf Karen. (1997). Why Do People Share Fantasies? An empirical investigation of a basic tenet of the symbolic convergence communication theory. Journal of Communication Studies, 48 (3), 254276.

Bungin, Burhan. (2014). Sosiologi Komunikasi.

Jakarta: KENCANA Prenamedia Group.

Carry W. James. (2009). Communication as Culture.

Essays on Media and Society. New York:

Routledge.

Dharma, F. A. (2018). Konstruksi Realitas Sosial :

Pemikiran Peter L . Berger Tentang Kenyataan

Sosial. Kanal: Jurnal Ilmu Komunikasi, 7(1), 1-9. 
Liliweri, Alo. (2014). Pengantar Studi Kebudayaan. Bandung: Nusa Media.

Littlejohn, Stephen, W., dan Karen, Foss, A. (2011). Theories Of Human Communication. Tenth Edition. Albuquerque. New Mexico: Wadsworth Publishing Company.

Muhammad, Arni. (2005). Komunikasi Organisasi. Jakarta: Bumi Aksara.

Sutaryo. (2005). Sosiologi Komunikasi. Yogyakarta: Arti Bumi Intaran. 


\section{BAB 6 \\ FENOMENOLOGI}

\section{Tujuan Instruksional Umum}

Setelah menyelesaikan Bab 6 mahasiswa diharapkan mampu:

1. Memahami tradisi fenomenologi dalam penelitian komunikasi lintas budaya.

2. Memahami aplikasi metode fenomenologi Edmun Husserl, Alfred Schutz, dan Peter L. Berger.

\section{Tujuan Instruksional Khusus}

Setelah mempelajari dan mengerjakan evaluasi di akhir Bab 6 ini mahasiswa diharpkan mampu:

1. Menjelaskan pengertian tradisi dan metode fenomenologi bagi penelitian komunikasi lintas budaya.

2. Mendiskusikan aplikasi metode fenomenologi Edmun Husserl, Alfred Schutz, dan Peter Ludwing Berger. 


\section{A. Tradisi Fenomenologi}

Tradisi fenomenologi, Menurut Gordon (1990: 612) sangat berhubungan dengan Edmund Husserl, seorang filsuf Jerman yang sangat menentang positivisme. Husserl berpendapat bahwa kebenaran yang diakui hanyalah kebenaran yang didapat melalui penelitian empiris, sedangkan dalam penelitian fenomenologi meyakini bahwa kebenaran datang darikesan mental internal manusia. Selama ini positivisme membatasi metodologinya pada hal-hal yang inderawi, dan fenomenologi berfokus pada "esensi" mereka sebagai manusia, yakni kekayaan batin.

\section{Pemikiran Feomenologi: Edmund Husserl, Alfred Schutz, Peter L. Berger dan Thomas Luckmann.}

Gordon (1990) menyebut fenomenologi sebagai cerminan dari tradisi panjang dalam filsafat yang melawan positivism dengan menekankan intuisi manusia sebagai fokus utama. Hal ini tentu tidak berdampak pada ilmu alam, dan jarang dibahas dalam literatur filsafat sains. Beberapa kritikus filsafat ilmu sosial berpendapat bahwa doktrin individualism dalam 
fenomena sosial harus dijelaskan dalam tindakan yang disengaja dari individu, dan dalam metodologi Max Weber tentang verstehen epistmologi fenomenologis mendapatkan tempatnya. Gagasan bahwa seseorang dapat memperoleh informasi yang berguna tentang perilaku manusia dengan introspeksi, dan bahwa ilmuwan sosial harus memperhatikan entitas mental seperti tujuan tindakan dan preferensinya, tidak sama dengan klaim bahwa pengetahuan apodiktif dunia dapat diperoleh dengan intuisi.

Dalam hal ini Immanuel Kant membuat perbedaan antara "fenomena" dan "noumena", yakni antara informasi mengenai hal-hal eksternal yang muncul dari interaksi antara sensasi dan alat kogitif manusia, serta hal-hal yang berasal dari dalam diri manusia. Fenomenologi menekankan perbedaanperbedaan ini. Bagi fenomenologi, sensasi tidak memberikan pengetahuan langsung tentang noumena; mereka hanya menghasilkan implus penghubun dalam saraf manusia yang harus diproses oleh otak sebelum memunculkan persepsi yang dapat dimengerti. Apa yang disebut sebagai informasi empiris, oleh karena itu tidak terjadi secara langsung, tetapi melalui 
beberapa langkah yang melibatkan penyaringan informasi dari obyek yang sedang dipikirkan. Ini tidak berarti bahwa empirisme harus ditinggalkan, seperti yang diklaim oleh ahli fenomenologi; ia lebih memilih untuk menilai peran yang dimainkan oleh "fakta" empiris dalam penyelidikan ilmiah yang lebih mendalam mengenai fakta-fakta yang terlihat secara empiris.

\section{B. Edmund Husserl}

Edmund Husserl disebut sebagai bapak atau pencetus pandangan fenomenologi dalam perkembangan ilmu sosial. Pemikiran Husserl muncul akibat dari kegelisahannya mengenai fakta-fakta kehidupan sehari-hari yang tidak diperhatikan oleh pandangan positivisme.

Pemikiran Husserl mengenai fenomenologi dipengaruh oleh gurunya, yakni Franz Brentano yang mengembangkan konsep fantasi dan memori. Husserl sangat memuji temuan gurunya tersebut, namun juga menyalahannya karena tidak dapat menjelaskan dengan baik tentang peran ketakutan dalam konstitusinya. Dalam hal ini Brentano menjelaskan 
perbedaan antara persepsi dan fantasi, antara presentasi perseptual, presentasi fantasi, dan presentasi simbolis? Antara presentasi intuitif dan yang tidak intuitif, presentasi kategoris dan sensual, dan sebagainya? (Husserl, 2005). Husserl menjadi semakin berminat terhadap filsafat, dari gurunya itu, yang mana kemudian Husserl sangat terpengaruh dengan pemikiran fenomenologi.

Lebih jelasnya Riyanto (2014: 25-26) menjelaskan bahwa metode berfilsafat fenomenologi ini muncul karena kegelisahan seorang Edmun Husserl. Ada pertanyaan besar yang muncul di benak seorang Husserl mengenai apa itu kebenaran. Apakah kebenaran itu seperti; (1) pandagan filosof skolastik yang mengajukan jawaban spekulatif dengan definisidefinisi logis, (2) pandangan filosof empiris yang yakin bahwa kebenaran itu harus dapat dibuktikan dengan pengalaman inderawi, (3) sosiolog positivitik yang mengangap bahwa pengetahuan mesti bertumpu pada observasi, data, dan statistik, sehingga dapat dibuktikan dalam perspektif eksperimental, kalkulatis, dan matematis, atau seperti (4) para psikolog yang 
meyakini telah menemukan inti manusia dengan aneka pengalaman terapisnya.

\section{Alfred Schutz}

Alfred Schutz adalah murid Edmund Husserl dan memperoleh pengaruh yang kuat dari Husserl dalam pemikirannya. Pemikiran Schutz menjembatani pemikiran fenomenologi Husserl yang bernuansa filsafat sosial dan psikologi dengan ilmu sosial yang berkaitan langsung dengan masyarakat.

Selain dipengaruhi oleh pemikiran Husserl, fenomenologi Schutz juga dipengaruhi oleh pemikiran Max Weber sehingga mengarahkan pemikiran Schutz pada gabungan analisis tindakan pemikiran model tipe ideal ala Weber dan model tipifikasi tindakan model Husserl. Tipifikasi tindakan ala Husserl ini digunakan oleh Schutz sebagai dasar untuk membangun pemikiran umum tentang dunia. Tipifikasi Husserl menjadi dasar terbangunnya tipifikasi tindakan yang didasarkan pada tipe tindakan aktor-aktornya, tipe tindakan dari tindakan itu sendiri, dan tipe tindakan yang didasarkan pada karakter sosial dari aktor dalam realitas kehidupan sehari-hari. Schutz mengkonstruksi 
metode ilmu sosial untuk mencoba identifikasi, mengklasifikasi, dan memperbandingkan model tindakan sosial secara luas namun sebagai sebuah fenomena menuju terbangunnya sebuah model tindakan baru. Model tindakan baru yang tidak yang secara komprehensif menggabungkan motif tindakan ala Weber dan jenis tindakan melalui tipifikasi ala Husserl (Wilson, 2002:4).

Schutz (1972) menyebutkan tindakan seseorang itu bermakna bagi orang yang melakukannya; hal ini yang membedakannya dengan sekedar perilaku. Dalam hal ini, referensi sosial tidak dibutuhkan. Setiap tindakan yang diarahkan kepada objek adalah ipso facto bermakna. Apabila saya mencelupkan pena kedalam tinta atau menghidupkan lampu baca, maka tindakan saya bermakna. Kita dapat menanggalkan konsep makna yang terdapat dimuka menuju ke medan sosial dan menggunakannya terhadap tindakan sosial, yang telah kita lihat, yang didasarkan pada perilaku orang lain.

Schutz membedakan makna dan motif. Makna berkaitan dengan apa yang penting dari kehidupan sosial aktor yang berpikir. Sementara motif 
adalah alasan seseorang melakukan sesuatu. Adapun makna memiliki dua tipe, yakni makna subyektif dan obyektif. Makna subyektif adalah konstruksi realitas tempat seseorang mendefinisikan komponen realitas tertentu yang bermakna baginya. Sedangkan makna obyektif adalah seperangkat makna yang ada dan hidup dala kerangka budaya secara keseluruhan yang dipahami secara bersama-sama oleh suatu kelompok masyarakat melebihi idiosinkratik. Schutz juga membedakan motif dengan dua tipe; "dalam kerangka untuk", dan "karena". Motif pertama berkaitan dengan alasan seseorang melakukan suatu tindakan sebagai usahanya untuk mnciptakan situasi dan kondisi seperti apa yang diharapkan. Sedangkan motif kedua adalah pandangan retrospektif terhadap faktor-faktor yang menyebabkan seseorang melakukan tindakan tertentu (Ritzer, 1983: 215).

\section{Peter L. Berger dan Thomas Luckmann}

Berger dan Lucmann (1990) memandang bahwa pada waktu itu aliran-aliran dalam sosiologi moderen memusatkan perhatiannya pada gejala perubahan sosial, gejla ketimpangan sosial atau gejala 
modernisasi. Bagi Berger aliran-aliran tersebut hanya memusatkan perhatian pada momen eksternalisasi, di mana semua individu yang mengalami sosialisasi secara tidak sempurna, bersama-sama membentuk kenyataan sosial yang baru.

Berger menyatakan bahwa aliran-aliran sosiologi moderen tidak cukup mampu menjelaskan asal-usul pengertian pranata sosial dan proses pembentukannya (seperti penglihatan ahli sejarah); juga percobaan mengaitkan sistem makna yang melekat pada lembaga-lembaga atau praktik-praktik institutional dan penerimaan bersama seperti yang digarisbawahi oleh para ideologi dan ahli indoktrinasi tentang suatu ideologi jika hanya melihat bagaimana struktur yang ada melegitimasi kekuasannya.

Menurut Berger dan Luckmann (1990: 34) pengetahuan akal sehat adalah pengetahuan yang dimiliki bersama-sama dengan masyarakat dalam rutinitas kehidupan sehari-hari. Kenyataan mengetahui pengetahuan ini sangat sulit untuk disangsikan karena sudah menjadi kebiasaan atau rutinitas dalam kehidupan bermasyarakat. 
Berger dan Luckmann mengembangkan dialektika konstruksi realitas sosial menjadi 3 momen, yakni: eksternalisasi, obyektivasi, dan internalisasi. Dalam eksternalisasi manusia dianggap sebagai produk lingkungan sosialnya dengan mengalami sosialisasi primer dan sekunder. Sosialisasi primer dialami saat usia dini dan lebih terjadi pada level kaluarga,yang mana keluarga adalah manifestasi dari kebudayaan masyarakat. Sosialisasi sekunder terjadi ketika manusia mulai beranjak dewasa dan bersentuhan dengan lingkungan sosial. Kemudian yang dimaksud obyektivasi adalah kenyataan obyektif yang dipercaya oleh masyarakat atau bagiamana kenyataan umum akhirnya memperoleh legitimasi. Kemudian yang terkhir adalah momen internalisasi, dimana sering disebut sebagai kenyataan obyektif, yakni di saat subyektifitas manusia menentukan perannya dalam masyarakat.

Berger dan Luckmann menjelaskan bahwa sosiologi pengetahuan memperoleh proposisi akarnya dari seorang Karl Marx, yakni bahwa kesadaran manusia ditentukan oleh keberadaan sosialnya. Konsepsi sosiologi pengetahuan ini memunculkan 
banyak perdebatan tentang bentuk determinasi sosial seperti apa dan bagaimana yang dimaksudkan oleh Marx.

Pertarungan pendapat mengenai determinasi sosial ini lebih tepatnya tidak terjadi pada jaman sosiologi pengetahuan Berger dan Luckmann, melainkan pada "zaman sosiologi klasik". Berger menyadarin bahwa Marx adalah peletak dasar konsepsi ini, namun Berger dan Luckmannlah yang dengan cerdik dan analitis, yang mampu mematenkan konsepsi ini.

Berger dan Luckmann (1990: 8) menyebutkan bahwa konsep sosiologi pengetahuan miliknya sangat terpesona dengan konsep kembar Marx mengenai "substruktur/superstruktur". Konsep kembar ini kemudian memantik perdebatan interpretatifnya. Marx cenderung mengiddentifikasi "substruktur" hanya dengan strutur ekonomi, lalu "superstrukturnya" diandaikan sebagai suatu refleksi yang langsung darinya.

Adalah Max Scheler yang kemudian meminjam skema "sub/superstruktur" Karl Marx untuk mengkonsepsikan sosiologi pengetahuan 
miliknya. Scheler lalu dengan pengertian bahwa ada semacam hubungan antara pemikiran dan suatu "kenyataan" yang mendasarinya (Berger dan Luckmann, 1990: 9).

Selain dipengaruhi oleh Marx Scheler, pemikiran Berger dan Luckmann (1966) mengenai konstruksi realitas dipengaruhi oleh landasan kehidupan sehari-hari yag dicetuskan oleh gurunya, yakni Alfed Schutz. Selain itu, berbagai pengandaian antropogisnya dipengaruhi oleh Marxian, terutama implikasi-implikasi antropologis yang telah ditarik dari biologi manusia oleh Helmuth Plessner, Arnold Gehlen dan lainnya. Mengenai kenyataan sosialnya, Berger dan Luckmann dipengaruhi oleh pemikiran Durkheim dalam mazhab sosiologi Perancisnya tentang "struktur", meskipun mereka telah memodifikasinya dengan konsep dialektis dari Marx dan pemberian tekanan kepada konstitusi kenyataan sosial melalui makna-makna subyektif yang diambil oleh Weber. Sementara itu, perandaian psikologisosialnya dipengaruhi oleh George Herbet Mead dan beberapa teoretisi yang mengembangkan madzhab interaksionisme simbolik dari sosiologi Amerika. 
Peter L. Berger bersama Thomas Luckmann memperjelas gagasan Husserl tentang dunia kehidupan yang lebih terbuka versi "subyektif" dari dominasi paradigm fungsionalis dalam sosiologi Amerika pada akhir 1960-an. Berger dan Luckmann memperkenalkan kembali obyek/subyek yang berbeda dalam inti teori pelembagaan sosiologis mereka. "Lifeworld" di sini menjadi realitas "sehari-hari", untuk dipahami sebagai interpretasi aktor sosial dalam sikap yang alami. Fenomenologi, dalam versi ini, lebih berhutang pada pemikiran Talcott Parsons daripada Edmund Husserl. Kemudian implikasi metodologis dan teoritis dari posisi ini dikembangkan oleh Harold Garfinkel sebagai "Ethnometodology", yang dianggap sebagai sekularisasi fenomenologi; sebuah pendekatan yang membatasi diri pada kritik konvensional positivism dalam ilmu-ilmu sosial dan menunjukkan kehidupan sehari-hari dari lokus aktor sosial (Garfinkel, 1967; Ferguson, 2001: 224).

\section{Ringkasan}

Fenomenologi hadir karena menentang logika positivisme dalam mencari kebenaran atau metode 
ilmiah. Selama ini positivisme membatasi metodologinya hanya pada hal-hal yang nampak, sementara fenomenologi berfokus pada "esensi" mereka sebagai manusia. Dalam bab ini dibahas 3 (tokoh) fenomenologi dari beberapa tokoh yang mendukung tradisi ini. Pertama adalah Edmun Husserl, yang lebih menekankan pada kondisi batin atau psikologis manusia sebagai obyek penelitian, kemudian Alfred Schutz yang mulai terpengaruh dengan pendapat Weber tentang tindakan sosial, sehingga fenomenologi Alfred Schutz dicirikan dengan adanya becouse of motif and becouse of mean dari individu ketika bertindak, sedangkan Peter L. Berger sudah memasukkan aspek budaya dalam fenomenologinya, sehingga metode yang digunakan lebih pada etnografi daripada fenomenologi sendiri.

\section{Pertanyaan Evaluasi dan Diskusi}

1. Jelaskan perbedaan metode positivistik dengan metode fenomenologi!

2. Jelaskan perbedaan fenomenologi Edmun Husserl, Alfred Schutz, dan Peter L. Berger! 
3. Diskusikan dengan teman anda contoh-contoh tema penelitian untuk fenomenologi Edmund Husserl, Alfred Schutz, dan Peter L. Berger!

\section{Referensi}

Berger, L. Peter, \& Luckmann, Thomas. (1966). The Social Construction of Reality. England: Penguin Group.

Berger, Peter L., Luckmann, Thomas. (1990). Tafsir Sosial atas Kenyataan: Risalah tentang Sosiologi Pengetahuan. Terj. Hasan Basari. Jakarta: LP3ES. Berger, Peter L. (1990). Revolusi Kapitalis. Terj. Mohamad Oemar. Jakarta: LP3ES.

Garfinkel, Harold \& Sacks, Harvey. 1986. Ethnometodological Studies, of Work. Edited by Harold Garfinkel. London: Routledge \& Kegan Paul Inc.

Gordon, Scott. (1990). The History and Philosophy of Social Science. London and New York: Routledge.

Husserl, Edmund. (2005). Phantasy, Image Consciousness, and Memory (1898-1925). 
Translated by: John B. Brough. Dordrecht: Springer.

Husserl, Edmund. (2006). The Basic Problems of Phenomenology. Translated by: Igno Farin \& James G. Hart. Dordrecht: Springer.

Ritzer, George. (1983). Sociological Theory. New York: Knopf Inc.

Riyanto, Armada, E. (2014). Berfilsafat Politik. Yogyakarta: Kanisius.

Schutz, A. (1972). The Phenomenology of Social

World. London: Heinemann Educational Books.

Wilson. Siloan, D., Sober, Elliott. (2002).

Phenomenology and Research Methodology for Information Behavior Research. Philosophy and Phenomenological Research. Vol. LXV, No. 3, Hlm. 711-727. 


\section{BAB 7 \\ STUDI GENDER DALAM KOMUNIKASI LINTAS BUDAYA}

\section{Tujuan Instruksional Umum}

Setelah menyelesaikan Bab 7 mahasiswa diharapkan mampu:

1. Memahami perbedaan makna gender dan jenis kelamin.

2. Memahami makna gender dalam kajian komunikasi lintas budaya.

\section{Tujuan Instruksional Khusus}

Setelah mempelajari dan mengerjakan evaluasi di akhir Bab 6 ini mahasiswa diharpkan mampu:

1. Menjelaskan pengertian gender dan jenis kelamin beserta contohnya.

2. Mendiskusikan makna gender dalam pandangan budaya-budaya yang ada di Indonesia. 


\section{A. Makna Gender dalam Komunikasi Lintas Budaya}

Gender adalah konsep untuk membedakan laki-laki dan perempuan bukan dari aspek biologis. Gender lebih banyak berkonsentrasi pada aspek sosial, budaya, dan psikologis, sehingga ngender sangat berbeda dengan sex atau jenis kelamin yang didasarkan atas aspek biologis atau hormon.

Studi gender lebih menekankan perkembangan maskulinitas atau feminitas seseorang, sedangkan studi sex lebih menekankan perkembangan aspek biologis dan komposisi kimia dalam tubuh lakilaki dan perempuan. Untuk proses pertumbuhan anak kecil menjadi seorang laki-laki atau menjadi seorang perempuan, lebih banyak digunakan istilah gender dari pada istilah seks. Istilah seks umumnya digunakan untuk merujuk kepada persoalan reproduksi dan aktivitas seksual, di luar itu digunakan istilah gender (Arbain dkk, 2015).

Sebagai contoh, pembagian peran suami-istri diniscayakan oleh istilah-istilah Jawa yang patriarkis. Misalnya istilah kanca wingking yang dilekatkan pada posisi dan peran istri. Kanca wingking dalam bahasa Indonesia diartikan sebagai teman belakang, yang 
kemudian bagi masyarakat Jawa dimaknai sebagai pengelola urusan rumah tangga, khususnya dalam mengurus anak, memasak, mencuci dan lainnya.

Chris Barker dalam bukunya yang berjudul "Cultural Studies" (2015) menyebutkan bahwa gender merupakan isu politis mengenai kekuasaan yang pada akhirnya menghadirkan gerakan feminisme. Feminisme lahir sebagai bentuk protes karena secara struktural perempuan selalu menjadi subordinat dari laki-laki.

Dalam hal ini Barker (2015) menjelaskan adanya dua aliran feminisme, yakni feminisme liberal dan feminisme sosialis. Feminisme liberal melihat peran perempuan sebagai dibentuk oleh sosioekonomi dan kultural. Oleh karena itu, budaya yang dinilai demokratis adalah budaya yang menjunjung tinggi kesetaraan. Sedangkan feminisme sosialis memandang peran perempuan telah dikebiri dalam hubungannya dengan kapitalisme. Perempuan tidak diperbolehkan mengambil posisi strategis dalam pekerjaa domestik.

Kendati demikian, Barker menyadari bahwa ada gerakan separatis dari feminisme lain yang 
mengatasnamakan sebagai feminisme perbedaan. Paham in memandang adanya perbedaan fundamental atau tidak dapat diubah secara kultural, psikis/dan atau biologis. Tiap budaya tidak selalu menampilkan perempuan sebagai subordinat dari laki-laki. Karenanya, pola komunikasi perempuan punya derajat yang berbeda di tiap tempat.

Retno Andriati (2016) dalam penelitiannya menyebutkan bahwa posisi perempuan tidak selamanya sub-ordinat. Para istri nelayan pesisir Tuban, Jawa Timur misalnya, yang rela menjadi pengemis di makam sunan Bonang pada musim paceklik untuk membantu perekonomian suaminya yang tidak bisa melaut karena cuaca buruk.

Foucault dalam Barker (2015) memeberi argumen antiesensialis, bahwa gender bukan hanya soal bagaimana budaya menerjemahkan hubungan biologis dengan peran sosial, melainkan kita digenderkan melalui kekuatan diskursus yang tertata dan regulatif. Diskursif, artinya gender bersifat representatif yang dapat berubah-ubah sesuai regulasi sosial-budaya. Perempuan dipandang sebagai agen 
sosial, bukan hanya aktor (yang hanya menjalankan peran sosial-budaya).

Berker menambahkan, bagi Sigmund Freud, hasrat seksual atau libido bisa ditentukan oleh fantasi. Dalam hal ini Freud ingin meneguhkan bahwa peran sosial juga dipengaruhi oleh fantasi atau "id-egosuperego" seseorang untuk berperan sebagai laki-laki atau perempuan. Psikoanalisis mempersoalkan pengalaman komunikasi pertama kali yang diperoleh oleh individu. Misalnya laki-laki secara komunikasi dibentuk untuk mandiri dan berani, sementara perempuan dibentuk untuk manja dan lemah-lembut sehingga mempengaruhi fantasi mereka pada cara berkomunikasi dan peran sosial yang akan dijalani.

Nilai-nilai pribadi sendiri dapat dilahirkan dan dibentuk melalui keluarga. Dalam skala yang lebih besar, keluarga merupakan hal yang pertama dan terpenting bagi seseorang untuk memperoleh keyakinan dan nilai-nilai budaya yang dijalankan dalam sistem keluarga. Sebuah keluarga dapat mengaplikasikan nilai-nilai budaya seperti pengambilan keputusan mengenai pekerjaan yang melibatkan gender, dinamika kekuasaan, dan 
hubungan sosial dengan orang lain dalam pengaturan suatu budaya (Ting-Toomey, 1999: 37).

\section{Ringkasan}

Gender adalah konsep yang dibuat untuk membedakan laki-laki dan perempuan dari aspek nonbiologis. Hal ini meliputi peran sosial dan budaya dari laki-laki dan perempuan yang sampai saat ini menjadi perdebatan. Maskulinitas dan feminitas terbentuk dari awal manusia mengalami sosialisasi primer, yakni melalui keluarga. Jika seorang anak laki-laki diajarkan nilai-nilai feminim, maka dia akan mengalami gangguan psikologis dan dianggap tidak normal. Karenanya, gender dan komunikasi lintas budaya sangat berhuibungan, karena nilai-nilai yang ada dalam keluarga besar dipengaruhi oleh nilai-nilai sosialbudaya. 


\section{Pertanyaan Evaluasi dan Diskusi}

1. Jelaskan perbedaan gender dan jenis kelamin, disertai dengan contohnya!

2. Diskusikan dengan teman anda, bagaimana komunikasi lintas budaya berperan dalam menentukan gender seseorang. Berikan contohnya!

3. Analisa simbol-simbol komunikasi yang melibatkan gender! Misalnya wanita malam, iklan rokok, dan lain sebagainya.

\section{Referensi}

Andriati, Retno. (2016). Buku Ajar Antropologi Maritim. Surabaya: PT. Revka Petra Media.

Arbain J., Azizah N., Sari, Ika N. (2015). PEMIKIRAN GENDER MENURUT PARA

AHLI: Telaah atas Pemikiran Amina Wadud Muhsin, Asghar Ali Engineer, dan Mansour Fakih. SAWAA, 11 (1), Pp. 75-93.

Barker, Chris. (2015). Cultural Studies: Teori dan Praktek. Terj.: Nurhadi. Yogyakarta: Kreasi Wacana.

Ting-Toomey, Stella. (1999). Communicating Across Culture. New York: The Guildford Press. 


\section{BAB 8 \\ ETNOGRAFI KOMUNIKASI}

\section{Tujuan Instruksional Umum}

Setelah menyelesaikan Bab 8 mahasiswa diharapkan mampu:

1. Memahami definisi folklor dan perkembangannya di era sekarang.

2. Memahami bentuk ataupun jenis folklor.

3. Memahami realitas dan komodifikasi pada folklor.

\section{Tujuan Instruksional Khusus}

Setelah mempelajari dan mengerjakan evaluasi di akhir Bab 4 ini mahasiswa diharpkan mampu:

1. Menjelaskan pengertian foklor dan perkembangannya di era sekarang.

2. Menjelaskan bentuk-bentuk dan jenis folklor yang ada di masyarakat.

3. Menjelaskan realitas dalam folklor dan bentuk komodifikasi folklor di era sekarang. 


\section{A. Etnografi dan Etnografi Komunikasi}

Menurut Engkus Kuswarno (2008) etnografi komunikasi adalah metode untuk memahami polapola komunikasi yang hidup dalam suatu masyarakat tutur, atau masyarakat yang memiliki kaidah yang sama untuk berkomunikasi. Inti dari etnografi komuinikasi adalah isu-isu mengenai bahasa, komunikasi dan kebudayaan.

Pendapat Kuswarno di atas tidak berbeda secara substansial dengan arti etnografi sendiri. Secara harafiah etnografi diartikan sebagai tulisan atau laporan menganai suatu suku bangsa yang ditulis oleh seorang antropolog dari hasil penelitian lapangan dalam kurun waktu yang cukup lama, yakni sekian bulan atau sekian tahun. Laporan penelitian etnografi begitu khas (Spradley, 2006).

Metode etnografi berkaitan dengan asal-usul disiplin antropologi. Kemunculan antropologi didasari oleh perkembangan evolusi budaya manusia dari awal manusia muncul di bumi sampai pada masa kini. Sementara itu kemunculan etnografi didasari oleh rasa curiga pada kerangka evolusi masyarakat dan budaya yang disusun oleh para ahli, yang mana para ahli 
tersebut tidak pernah melihat sendiri kelompok masyarakat yang menjadi obyek kajiannya.

Metode etnografi berusaha mendeskripsikan suatu kebudayaan. Tujuan utama aktivitas ini untuk memahami suatu pandangan hidup dari sudut pandang penduduk asli (yang diteliti). Hal ini sejalan dengan penjelasan Malinowski (Spradley, 2006: 4) bahwa tujuan etnografi adalah untuk memahami sudut pandang penduduk asli, hubungannya dengan kehidupan, untuk mendapatkan pandangannya mengenai dunianya. Inti dari etnografi adalah usaha untuk memperhatikan dan memahmi makna-makna tindakan dari kejadian yang dialami oleh orang yang ingin kita pahami. Beberapa makna tersebut terekspresikan secara langsung dalam bahasa; dn di antara makna-makna tersebut ada pula yang disampaiakan melalui bahasa nonverbal.

Seperti yang telah dijelaskan di atas bahwa metode etnografi tidak dapat dipisahkan dari disiplin antropologi. Oleh karena itu, mempelajari etnografi bararti juga mempelajari kebudayaan. Kebudayaan menurut Spradley merujuk pada pengetahuan yang diperoleh, yang digunakan orang untuk 
menginterpretasikan pengalaman dan melahirkan tingkah laku sosial.

Dalam melakukan kerja lapangan, etnografer membuat kesimpulan budaya melalui tiga sumber: (1) dari yang dikatakan orang, (2) dari cara orang bertindak, dan (3) dari berbagai artefak yang digunakan orang. Tiga sumber tersebut secara bersama-sama dapat membentuk deskripsi budaya secara tepat dank has.

Salah satu yang penting dalam metode etnografi adalah pendeskripsian secara detail teoriteori penduduk asli yang telah diuji dalam situasi kehidupan actual selama beberapa generasi atau meniscayakan grounded theory. Setelah memahami kepribadian masyarakat, individu-individu, dan lingkungan dari perspektif yang lain dari perspektif kebudayaan ilmiah profesional, maka kita akan sampai pada sikap epistemologis yang rendah hati dan menghindarkaan diri dari etnosentrimes (Spradley, 2006: 16). 


\section{B. Pentingnya Bahasa}

Pada saat berhadapan langsung dengan penduduk asli, seorang etnografer harus berhadapan dengan dua bahasa, yakni bahasa yang digunakan oleh etnografer dan bahasa yang digunakan oleh informan. Dalam hal ini Spradley membagi tugas etnografer menjadi dua, yaitu penemuan (discovery) dan deskripsi.

Bahasa bukan sekedar alat untuk mengkomunikasikan realitas. Lebih dari itu, bahasa merupakan alat untuk menyusun realitas. Bahasa yang berbeda akan menciptakan ekspresi yang berbeda pula. Perbedaan bahasa akan mengkategorikan pengalaman denan cara yang berbeda. Bahasa yang berbeda memberikan pola-pola alternative untuk berpikir dan memahami. Oleh karena itu, mempelajari bahasa adalah hal yang paling pertama harus dilakukan oleh etnografer.

Spradley mulai meguji idenya dengan cara berkomunikasi dengan anaknya yang masih kecil dan Spradley menemukan bahwa bahasa yang digunakan oleh anaknya saat di rumah berbeda dengan bahasa yang digunakan di sekolah saat berkomunkasi dengan 
teman sebayanya. Spradley sampai pada kesimpulan bahwa etnografer yang bekerja di dalam masyarakatnya sendiri harus mempelajari bahasa sama halnya dengan etnografer yang berasal dari luar daerah masyarakat yang sedang diteliti.

\section{Apa itu Informan?}

Informan merupakan sumber informasi atau secara harafiah diartikan sebagai guru bagi etnografer (Spradley, 2006: 39). Kebanyakan orang tanpa sadar dapat menjadi informan pada suatu waktu. Misalnya seseorang ang biasa memberikan informasi pada orang lain mengena kehidupannya hingga masa lalunya.

Hubungan antara informan dengan etnografer seringkali dikaburkan oleh hubungan yang lain. Tidak jarang informan curiga pada orang asing yang tibatiba masuk dalam kehidupan sosial-budaya, bahkan yang lebih pribadi dari mereka. Oleh karena itu, seorang etnografer harus dapat meyakinkan informannya untuk percaya jika tujuan informan hanya meneliti dan tidak memiliki tujuan yang jahat pada mereka. Hubungan antara informan dengan 
etnografer juga dapat dikacaukan oleh peran-peran ilmu sosial yang lain. Terdapat tiga peran dalam ilmuilmu sosial yang berbeda dengan peran informan, yakni: subyek, responde, dan pelaku.

Penelitian yang menggunakan subyek biasanya memiliki tujuan tertentu, seperti penelitian yang ingin menguji hipotesis atau eksperimental. Penelitian semacam itu tidak tertarik untuk menemukan pengetahuan budaya dari subyek. Mereka hanya ingin menegaskan atau membatalkan suatu hipotesis tertentu dengan mempelajari jawaban dari subyek.

Penjelasan di atas berbeda dengan responden. Kendati sama-sama berada dalam logika positivistic, bentuk responden hampir serupa dengan informan, yakni sama-sama menjawab seluruh daftar pertanyaan yang diajukan oleh peneliti. Bedanya, jika responden harus menjawab dengan bahasa yang telah ditentukan oleh peneliti, maka seorang informa dapat menjawab daftar pertanyaan yang diajukan dengan bahasa mereka sendiri.

Terakhir adalah pelaku. Seorang pelaku adalah obyek pengamatan dalam suatu setting alam. 
Etnografer seringkali menjadikan pelaku sebagai informan dalam penelitiannya, misalnya pada seorang hakim yang sedang mengamati terdakwa. Namun, tidak semua pelaku dapat dijadika sebagai informan, misalnya seorang dokter yang sedang mengamati bayi, seorang peneliti yang sedang mengamati gorilla, dan lain sebagainya.

Informan adalah manusia biasa yang juga memiliki permasalahan hidup, keprihatinan, dan kepentingan. Nilai yang dipegang oleh etnografer tidak selamanya sejalan dengan nilai yang dipegang oleh informan. Etika yang harus dipegang oleh etnografer adalah menjaga perasaan informannya. Etnografer hendaknya mempertimbangkan informan terlebih dahulu, mengamankan hak-hak, kepentingan, dan sensitivitas informan, menyampaikan tujuan penelitian, melindungi privasi informan, tidak terlalu mengeksploitasi informan, dan memberikan laporan penelitian pada informan.

\section{a. Menetapkan Informan}

Tujuan dari penetapan informan ialah untuk mengidentifikasi karakteristik dari informan 
yang baik dan meemukan informan yang sesuai dengan kebutuha penelitia etnografi yang sedang dilakukan. Walaupun hampir setiap orang dapat menjadi informan, namun tidak semua orang dapat menjadi informan yang baik.

Dalam melakukan wawancara pada informan, seorang etnografer sangat bergantung pada sejumlah keterampilan interpersonal, seperti: keterampilan mengajukan pertanyaan, mendengarkan, mengambil sikap pasif, meampakkan minat verbal terhadap orang lain, dan menunjukkan minat degan bahasa non verbal (Spradley, 2006: 67). Spradley mengidentifikasi lima persyaratan minimal untuk memilih informan yang baik, yakni: (1) enkulturasi penuh, yakni seseorang yang megalami pembelajaran budaya secara alami, (2) keterlibatan langsung, yakni sebagai pelaku dari apa yang sedang diteliti, (3) suasana budaya yang tidak dikenal, yakni seseorang yang mampu mempelajari perbedaan budaya di antara etnografer dan informan, (4) waktu yang cukup, yakni seseorang yang mudah ditemui, dan (5) non-analitis, yakni seseorang 
yang mampu menjelaskan segala sesuatu dengan pendekatan teori penduduk asli.

\section{b. Mewawancarai Informan}

Tujuan dari bahasan ini ialah mengidentifikasi unsure-unsur dalam wawancara etnografis, memformulasikan dan menggunakan beberapa macam penjelasan etnografis, serta dapat melakukan wawancara praktis. Sebagai seorang etnografer, kita dapat melihat beberapa unsure wawancara etnografis berikut: (1) tujuan yang eksplisit, yakni mengetahui arah pembicaraan sesuai dengan data yang ingin didapat, (2) penjelasan etnografis, yakni ketika etnografer mempelajari budaya informan, maka informan pun memiliki kesempatan untuk belajar mengenai beberapa hal dari etnografer, (3) pertanyaan etnografer, yakni terdiri dari pertanyaan deskriptif, pertanyaan structural, dan pertanyaan kontras.

\section{Membuat Catatan Etnografis}

Suatu catatan etnografis meliputi catatan lapangan, alat perekam, gambar, artefak, dan benda- 
benda lain yang dapat mendokumentasikan suasana budaya yang sedang dipelajari (Spradley, 2006: 96). Bagian utama dari catatan etografis terdiri atas catatan-catatan lapagan yang tertulis seperti catata hasil observasi, wawancara, rekaman, buku harian, dan catatan dokumen lainnya.

Dalam membuat catata etnografis, kita hendaknya selalu mempertimbangkan prinsip identifikasi bahasa. Dalam hal ini Spradley memberi contoh kasus pada kehidupan gelandangan dengan mengidentifikasi bahasa-bahasa yang terlibat dalam penelitian, seperti bahasa peneliti, bahasa gelandangan, bahasa ruangan pengadilan, dan bahasa pusat perawatan alkoholisme. Hal ini penting untuk dilakukan agar peneliti dapat mengkategorikan dan menyusun catatan dengan baik.

\section{E. Mengajukan Pertanyaan Deskriptif}

Kata kunci dari proses ini ialah membina hubungan yang baik dengan informan agar menceritakan budaya yang dimilikinya. Dengan demikian seorang etnografer harus membangun 
kepercayaan pada informan agar arus informasi semakin mudah didapatkan.

Satu prinsip kunci dalam mengajukan pertanyaan etnografis ialah memperluas pertanyaan, sehingga dapat memperluas jawaban. Misalnya pertanyaan "dapatkah anda menceritakan kepada saya, seperti apa penjara itu?" yang masih membutuhkan perluasan seperti "saya belum pernah masuk ke dalam penjara, sehingga saya tidak mempunyai banyak ide tentang bagaimana penjara itu. Dapatkah anda menunjukkan dan menceritakan kepada saya bagaimana penjara itu, apa yang dapat saya lihat jika saya masuk ke dalam penjara dan berjalan berkeliling? Dapatkah anda menceritakan kepada saya seperti apa penjara itu?"

\section{F. Melakukan Analisis}

Dalam banyak penelitian ilmu sosial, urutan analsis wawancara mengikuti tahapan berikut: (1) memilih masalah, (2) memformulasikan hipotesis, (3) mengumpulkan data, (4) menganalisis data, (5) menuliskan hasil. Sedangkan dalam penelitian etnografi dimulai dengan: (1) memilih masalah, (2) 
mengumpulkan data kebudayaan, (3) menganalisis data kebudayaan, (4) memformulasikan hipotesis etnografis, (5) menuliskan etnografi.

Fokus utama dalam analsis wacana etnografi ialah menemukan makna budaya, dan oleh karena itu dalam bagian ini Spradley menngunakan teori relasional makna untuk memikirkan ada makna apa dibalik makna yang kita gunakan. Seperti makna tertawa, ketika seseorang tertawa pada kita maka kita harus mencari tahu apakah orang tersebut menertawai kita atau mengajak kita tertawa.

Selanjutnya simbol, yang merupakan obyek atau peristiwa apa pun yang menunjuk pada sesuatu. Dalam hal ini simbol adalah istilah-istilah penduduk asli (lokal) yang digunakan oleh informan. Selain simbol ada juga yang disebut sebagai sistem makna, yakni menanyakan kegunaan dari makna yang dihadirkan. Prinsip ini didasarkan pada teori relasional tentang makna. Informan hampir selalu menjawab dengan definisi singkat, yaitu definisi referensial. Setelah etnografer menanyakan kegunaannya, maka informan akan menghubungkannya dengan istilahistilah lain. 
Secara singkat Spardley meyebutkan dasar teori relasional tentang makna sebaga berikut:

1. Sistem makna budaya disandikan oleh simbolsimbol.

2. Bahasa merupakan sistem simbol utama yang menyandikan makna budaya dalam setiap masyarakat. Bahasa dapat digunakan untuk menyampaikan simbol lain yang diandaikan.

3. Makna simbol apa pun merupakan hubungan dari simbol itu dengan simbol yang lain dalam suatu budaya tertentu.

4. Tugas etnografi adalah memberi sandi simbolsimbol budaya serta mengidentifikasikan aturanaturan penyandian yang mendasarinya.

\section{a. Membuat Analisis Domain (Penduduk Asli)}

Tujuan dari bagian ini adalah memahami sifat dasar hubungan semantic serta peran hubungan itu dalam pembuatan suatu analisis domain, mengidentifikasi langkah-langkah dalam menjalankan analisis domain, melakukan analisis domain sistematis terhadap semua data yang terkumpul sekarang, dan untuk memasukkan pertanyaan-pertanyaan structural ke dalam wawancara etnogafris. 
Setiap bahasa mengandung banyak sekali istilah penduduk asli yang dapat digunakan untuk merujukkan hal-hal yang mereka alami; nama-nama benda, peristiwa, kualitas, proses, serta tindakan. Etnografer hendaknya berfokus pada hubugan semantic yang diekspresikan oleh informan sebagai pemilik makna.

Prosedur-prosedur yang disebut sebagai analisis domain terdiri atas enam langkah yang saling berkaitan, yakni:

1. Memilih satu hubungan semantic tunggal;

2. Menyiapkan satu kertas kerja analisis domain;

3. Memilih satu sampel dari beberapa statemen informan;

4. Menemukan istilah-istilah pencakup serta istilah-istilah tercakup yang benar-benar sesuai dengan hubungan semantic tersebut;

5. Memformulasikan pertanyaan-pertanyaan structural untuk masing-masing domain; dan

6. Membuat daftar semua domain yang telah menjadi hipotesis etnografi. 


\section{b. Mengajukan Pertanyaan Struktural}

Pertanyaan structural ialah penyesuaian tiap pertayaan agar menjadi satu kesatuan yang dapat mendeskripsikan. Pertanyaan structural ini bukan menggantikan pertanyaan deskriptif, malainkan sebagai pelengkap. Bedanya, jika pertanyaan deskriptif menginginkan adanya deskripsi yang lengkap, maka pertanyaan structural mengarahkan dan membatasi jawaban informan. Misalnya, "apa jenis mobil yang anda beli?" "mobil-mobil apa saja yang ingin anda beli?"

\section{c. Membuat Analisis Taksonomik}

Melalui pertanyaan deskriptif dan structural seorang etnografer telah mendapatkan suatu bangunan informasi budaya yang berkembang. Dengan membuat analisis taksonomi, maka etnografer sudah mulai melakukan analisis yang lebih mendalam tentang domain-domain yang terpilih.

Tujuan dari analisis taksonomik ialah untuk memilih suatu fokus yang bersifat sementara untuk membuat analisis mendalam, memahami 
berbagai taksonomi rakyat dan bagaimana taksonomi itu mengorganisir domain, mempelajari bagaimana membuat analisis taksonomik, membangun suatu taksonomik rakyat untuk satu domain atau lebih dengan mengikuti langkahlangkah dalam mengerjakan analisis taksonomik. Adapun langkah-langkah dari analisis taksonomik adalah:

1. Memilih suatu domain untuk analisis taksonomik.

2. Identifikasi kerangka substitusi yang tepat untuk dianalisis.

3. Carilah subset yang memungkinkan di antara beberapa istiah tercakup.

4. Carilah domain yang lebih besar, lebih inklusif yang dapat masuk ke dalam suatu subset yang sedang anda analisis.

5. Membuat taksonomi sementara.

6. Formulasikan pertanyaan structural untuk membuktikan berbagai hubungan taksonomik dan memperoleh berbagai istilah baru.

7. Melakukan wawancara structural tambahan.

8. Membuat taksonomi yang lengkap. 


\section{d. Mengajukan Pertanyaan Kontras}

Pertanyaan kontras diperlukan untuk menegaskan bahwa suatu simbol dapat ditemukan dengan menemukan bagaimana suatu simbol berbeda dengan simbol-simbol lain. Pendapat ini didasarkan pada kenyataan bahwa istilah rakyat bergantung pada apa yang bukan menjadi maknanya. Misalnya ketika menyebutkan "lakilaki”, apakah anak laki-laki itu bayi, anak kecil, remaja, dewasa, atau sudah tua? Semuanya memiliki makna yang berbeda bagi budaya tertentu.

Dalam hal ini ada tujuh pertanyaan kontras, yakni: (1) pertanyaan pembuktian perbedaan, (2) pertanyaan perbedaan langsung atau langsung menanyakan perbedaan makna yang dimaksud, (3) pertanyaan perbedaan diadik untuk mendapatkan istilah yang tidak diketahui oleh etnografer, (4) pertanyaan perbedan triadic atau terjadi saling bertanya antara etnografer dengan informan untuk mendapatkan makna yang lebih jelas dan lengkap, (5) pertanyaan yang memilih rangkaian kontras, (6) permainan dua puluh pertanyaan, (7) pertanyaan ranting sebagai cara 
mendapatkan atau menemukan nilai-nilai yang ada dalam berbagai rangkaian simbol. Kesemuanya itu dijadikan sebagai dasar untuk melakukan analisis komponen atau melengkapi istilah-istilah kontras dengan atribut yang melekat.

\section{e. Menemukan Tema-tema Budaya}

Konsep mengenai tema budaya berakar pada gagasan umum, bahwa kebudayaan adalah lebih dari potongan-potongan kebiasaan, dan merupakan pola yang kompleks. Tema-tema budaya merupakan unsure-unsur dalam peta kognitif yang membentuk suatu kebudayaan. Dalam bagian ini Spradley menunjukkan beberapa tema-tema kebudayaan universal yang dapat membantu etnografer, yakni: konflik sosial, kontradiksi budaya, menata hubungan sosial impersonal, mendapatkan dan mempertahakan status, dan menyelesaikan masalah.

\section{G. Menulis Laporan Etnografi}

Ini merupakan proses terakhir dalam rangkaian penelitian etnografi. Menurut Spradley, 
penulisan etnografi hendaknya dimulai dari hal umum ke yang khusus. Dalam hal ini Spradley telah merumuskan tahapan-tahapannya sebagai berikut:

1. Statemen-statemen universal, yakni meliputi semua statemen mengenai umat manusia, tingkah laku mereka, kebudayaan mereka, dan keadaan situasional mereka.

2. Statemen-statemen deskriptif lintas budaya.

3. Statemen umum mengenai suatu masyarakat atau kelompok budaya.

4. Statemen umum mengenai suatu suasana budaya yang spesifik.

5. Statemen spesifik mengenai suatu domain budaya.

6. Statemen insiden spesifik, yakni tahapan menerjemahkan tingkah laku obyek penelitian.

Sementara itu, dalam menulis suatu etnografi, Spradley telah merumuskan langkah-langkahnya sebagai berikut: (1) memilih khalayak, (2) memilih tesis, (3) membuat daftar topic dan garis besar, (4) menulis naskah kasar untuk masing-masing bagian, (5) merevisi garis besar dan membuat anak judul, (6) 
mengedit naskah kasar, (7) menuliskan pengantar dan kesimpulan, (8) menuliskan kembali tulisan mengenai contoh-contoh, (9) menulis naskah akhir.

\section{Ringkasan}

Pada dasarnya, etnografi komunikasi juga berakar pada disiplin antropologi. Etnografi komuikasi adalah metode yang digunakan untuk menggambarkan pola-pola komunikasi yang hidup dalam suatu masyarakat tutur, atau masyarakat yang memiliki kaidah yang sama untuk berkomunikasi. Penelitian etnografi relatif membutuhkan waktu yang lama karena berusaha menggambarkan budaya masyarakat secara obyektif tanpa adanya bias budaya melalui beberapa tahapan penelitian dengan menguji hasil wawancara dengan observasi partisipan. 


\section{Pertanyaan Evaluasi dan Diskusi}

1. Jelaskan apa yang dimaksud dengan etnografi komunikasi!

2. Buatlah proposal penelitian dengan menggunakan metode etnografi sesuai dengan tahapantahapannya!

\section{Referensi}

Kuswarno, Engkus. (2008). Etnografi Komunikasi:

Suatu Pengantar dan Contoh Penelitiannya. Bandung: Widya Padjadjaran.

Spradley, P. James. 2006. Metode Etnografi. Terj. Misbah Zulfa E. Yogyakarta: TIARA WACANA. 


\section{BAB 9 \\ ETNOGRAFI VIRTUAL}

\section{Tujuan Instruksional Umum}

Setelah menyelesaikan Bab 9 mahasiswa diharapkan mampu:

1. Memahami metode etnografi virtual.

2. Memahami perbedaan etnografi virtual dengan etnografi konvensional.

3. Memahami teknis penelitian etnografi virtual.

\section{Tujuan Instruksional Khusus}

Setelah mempelajari dan mengerjakan evaluasi di akhir Bab 9 ini mahasiswa diharpkan mampu:

1. Menjelaskan pengertian etnografi virtual.

2. Menjelaskan perbedaan etnografi virtual dengan etnografi konvensional.

3. Menjelaskan langkah-langkah melakukan penelitian etnografi virtual. 


\section{A. Komunikasi Virutal}

Kita hidup di persimpangan sejarah dimana dunia maya dan game online berdiri mengkonfigurasi ulang karakter " budaya" kita. Selain itu, terjadi pula revolusi komunikasi dalam berbagai cara manusia berdialog dan dengan perubahan sosiopolitik, sosiopsiko, serta sosiokultur yang dapat disebut sebagai "globalisasi".

Celia Pearce dan Artemesia dalam bukunya yang berjudul "Communities of Play" (2009) menyebutkan bahwa dalam konteks dunia maya dan game online sebuah pertaruan yang besar bagi dunia akademisi adalah menegembagkan sebuah kerangka teotitis dan metodologis yang baru untuk menjelajahi dunia virtual.

Dalam konteks inilah komunitas bermain dilihat dengan tiga cara yang berbeda oleh Pearce. Pertama, Pearce mengeksplorasi sebuah pergerakan komunitas daring ke dalam dunia permainan virtual. Pearce fokus pada hubungan antara dunia virtual dan dunia maya. Kedua, sebagai seorang antropolog, Pearce melakukan banyak penelitian secara aktual 
untuk mengembangkan metode etnografi. Ketiga, pengalaman Pearce sebagai desainer game membuatnya percaya budaya masa depan akan muncul, dan yang tidak dapat kita pahami hanya dalam hal tindakan individu dan keyakinan mereka. Dengan demikian Pearce kembali lagi pada pendekatan fungsionalis klasik dan strukturalis klasik.

Studi tentang dunia virtual memperoleh daya tarik cepat di dunia akademis. Dalam beberapa tahun singkat, arena penelitian multidisiplin muncul dengan partisipasi dari para peneliti media, studi organisasi, pendidikan, antropologi, dan bidang komputer sebagai interaksi manusia-komputer dan kerja kolaboratif yang didukung oleh komputer.

Hine (2000: 9) menyebutkan bahwa keyakinan tentang internet mungkin memiliki konsekuensi penting untuk cara kita menjalin hubungan dengan teknologi dan satu sama lain melalui internet. Oleh karena itu, etnografi dapat digunakan untuk mengembangkan pemahaman yang mendalam tentang makna teknologi dan budaya yang memungkinkannya dan dimungkinkan olehnya. Hine mengambil titik 
awal yang dialogis dengan proyeksi teoritis dari signifikansi internet, kegunaan internet sebagai latar belakang masalah untuk etnografi penggunaan internet sebagai media komunikasi. Pertanyaan penelitian spesifik yang diangkat oleh tinjauan teoritis adalah:

1.Bagaimana pengguna internet memahami kapasitasnya? Apa signifikansi penggunaannya bagi mereka? Bagaimana mereka memahami kapabilitas internet sebagai media komunikasi, dan bagaimana cra mereka memandang audiens mereka?

2.Bagaimana internet mempengaruhi pengaturan waktu dan ruang hubungan sosial? Apakah ini berbeda dengan cara yang dilakukan di kehidupan nyata, dan jika demikian, bagaimana pengguna mempertemukan keduanya?

3. Apakah implikasi internet terhadap keaslian dan keotentikan? Bagaimana identitas dibentuk dan dieksekusi, dan cara mereka menilai keasliannya?

4. Apakah pengalaman "yang virtual: sangat berbeda dan terpisah dari yang sebenarnya? Apakah ada batasan antara online dan offline? 
Perhatian dengan efek yang mungkin dimiliki Communication Mediated Computer (CMC) pada proses komunikasi hampir sama mapannya dengan teknologi itu sendiri. Pendekatan awal untuk mempelajari $\mathrm{CMC}$ masih jauh dari pengakuannya sebagai situs untuk pertukaran budaya yang kaya. Dibandingkan dengan media komunikasi lain dan khususnya dibandingkan dengan interaksi tatap muka yang terlihat lebih kaya komunikasi (Hine, 2000: 15).

James Lull (2001) menyebtukan bahwa pertukaran simbolik yang difasilitasi oleh teknologi tinggi dan jaringan baru merupakan aktifitas mendasar dalam komunikasi manusia. Meskipun teknologi informasi telah sangat mempercepat dan mengubah beberapa cara manusia dalam berkomunikasi satu sama lain, motivasi di balik praktik penting yang diciptakan orang untuk membangun dunia sosial dan budaya mereka tetap tidak berubah secara fundamental. Pentingnya proses komunikasi adalah saat mereka melibatkan seluruh jajaran sumber daya material dan simbolik yang mereka miliki. Sumber daya tersebut tidak hanya mencakup bentuk simbolis yang dimediasi oleh komputer, tetapi seluruh dari 
pengaruh budaya tradisional yang kurang dimediasi, yang pada kahirnya taken for granted pada kehidupan sehari-hari.

Tidak seperti pada era sebelumnya, ketika nilai dan cara hidup dikaitkan terutama dengan konteks dan pengaruh lokal, bentuk budaya saat ini beredar jauh lebih luas dan digunakan dengan cara yang semakin inovatif. Perebutan budaya dan identitas dalam skala global telah menjadi masalah inti bagi para akademisi di berbagai disiplin ilmu dalam ilmu sosial dan humaniora.

Teknologi komunikasi telah menjadi penentu dalam transformasi sosiokultural yang terjadi di seluruh dunia. James Lull mencoba untuk memperhitungkan sepenuhnya perkembangan teknologi dalam aktivitas budaya kontemporer, termasuk nuansa dan seluk-beluk komunikasi yang dimediasi oleh komputer, tetapi ia juga mempertimbangkan sisi kehidupan yang lebih dialami secara langsung dan "non-rasional". Emosi manusia dan pengalaman rutin sehari-hari adalah faktor-faktor yang sering diabaikan dalam diskusi teoretis tentang 
budaya dan masyarakat di era komunikasi menjadi fokus utama dalam kajian yang dilakukan oleh James Lull.

Untuk mendapatkan seluk-beluk komunikasi dalam dunia virtual, Pearce (2009) menjelaskan bagaimana dia sendiri muncul sebagai peserta dalam komunitas virtual yang dia pelajari. Tapi ini bukan tentang dia, ini tentang komunitas. Dia menggunakan diskusi tentang pengembangan identitasnya sebagai peserta khusus untuk tidak berbicara tentang dirinya sendiri, tetapi untuk mengungkapkan dinamika komunitas yang dia selidiki. Ini merupakan strategi pengumpulan data etnografi virtual yang harus dilalui oleh seorang etnografer.

Kendati demikian, ketergantungan pada data elektronik dapat menimbulkan beberapa masalah bagi analisis data etnografik. Secara tradisional, validitas pengamatan etnografer atas luasnya pengamatan dan partisipasi yang dimiliki berkontribusi pada temuan. Mengingat etnografer didukung dan terlibat kehadirannya, tampaknya tidak mungkin bahwa informan bisa menjaga keaslian identitas dirinya 
(Hine, 2000: 22). Oleh karenanya Hine (2000: 45-46) menyebutkan pentingnya bagi seorang etnografer virtual untuk memiliki pengalaman dan pengetahuan yang luas tentang apa yang akan dan sedang diteliti di dunia maya.

Perihal lama waktu penelitian, Achmad dan Ida (2018) menyebutkan bahwa tidak ada batasan yang pasti, semuanya bergantung pada kebutuhan penelitian. Menurut Achmad dan Ida (2018) etnografi virtual lebih dari etnografi pada umumnya yang bersifat observasi partisipan. Hal ini terjadi karena melalui media siber seorang etnografer bisa menggunakan banyak metode pengumpulan data, termasuk kuesioner dan wawancara semistruktur secara tatap muka. Pengumpulan data secara offline ini dapat menunjang orisinalitas atau kebenaran data yang disampaikan oleh informan.

\section{B. Prinsip Etnografi Virtual}

Hine (2000: 63-65) mengemukakan adanya perbedaan etnografi konvensional dengan prinsipprinsip metode etnografi virtual sebagai berikut: 
1. Kehadiran seorang etnografer secara berkelanjutan dalam setting lapangan (dunia virtual), disisir dengan keterlibatan intensif pada kehidupan seharihari komunitas di lapangan, membuat jenis pengetahuan khusus yang kita sebut sebagai etnografi. Seorang etnografer juga mencari data secara berulang-ulang dan berkelanjutan untuk mengurangi kebingungan atau ketidakpastian. Etnografi virtual digunakan sebagai perangkat penelitian yang menggunkaan pengunaan internet sebagai problematik.

2. Media interaktif memberikan tantangan dan peluang untuk etnografi, dengan mempertanyakan pengertian dari sebuah situs interaksi. Cyberspace tidak boleh dianggap sebagai ruang yang terpisah dari kehidupan nyata dan interaksi tatap muka. Media interaktif seperti internet bisa dipahami sebagai artefak budaya dan budaya itu sendiri.

3. Pertumbuhan interaksi yang dimediasi oleh internet mengubah lokasi penelitian. Interaksi yang terjadi di internet selalu bergerak sehingga menjadi peluang besar bagi etnografer untuk melihat 
bagaimana komunitas virtual itu dibuat dan dibuat kembali.

4. Sebagai konsekuensinya, konsep lokasi lapangan menjadi pertanyaan penting. Jika budaya dan komunitas tidak dengan sendirinya terletak pada tempatnya, maka begitu pula etnografi yang harus memfokuskan diri pada arus informasi dan konektivitas antar user.

5. Batasan tidak diasumsikan secara apriori tetapi dieksplorasi sepanjang etnografi. Tantangan etnografi virtual adalah menjelajahi pembuatan batasan dan pembuatan koneksi, khususnya antara dunia virutal dan nyata. Oleh karenanya etnografer juga harus tahu kapan dia berhenti. Menghentikan penelitian etnografi menjadi keputusan pragmatis. Hal ini dibatasi oleh kendala etnografer dalam waktu, ruang, dan kecerdasan.

6. Seiring dengan dislokasi spasial muncul dislokasi temporal. Kehidupan pengguna internet tidak terjadi 24 jam, tidak menggambarkan budaya secara utuh.

7. Etnografi virtual merupakan bagian dari deskripsi holistik informan, lokasi atau budaya yang tidak 
mungkin dicapai. Kesulitannya adalah menjangkau informan, lokasi bahkan budaya secara utuh.

8. Etnografi virtual melibatkan keterlibatan intensif etnografer dengan mediasi interaksi. Jenis keterlibatan ini menambahkan dimensi baru atau pengalaman etnografer dalam bermedia sosial. Pembentukan interaksi antara etnografer dengan informan oleh teknologi adalah bagian dari etnografi, seperti halnya interaksi etnografer dengan teknologi.

9. Kehadiran interaksi antara etnografer dan informan harus dapat dirasakan. Semua bentuk-bentuk interaksi valid secara etnografis, bukan hanya tatap muka. Oleh karenanya, kehadiran komunikasi tatap muka tidak diperlukan lagi.

10. Etnografi virtual tidak dapat disamakan dengan etnografi pada umumnya. Etnografi virtual cukup untuk tujuan praktis mengeksplorasi hubungan interaksi yang dimediasi, sehingga pada dimensi ini etnografi virtual cukup mengambarkan kondisi yang mendekati nyata dalam ruang siber. Ini adalah etnografi adaptif yang ditetapkan untuk 
menyesuaikan etnografer dengan kondisi ruang siber.

\section{Langkah-langkah Etnografi Virtual}

Zainal Abidin Achmad dan Rachma Ida (2018) menjelaskan lima langkah yang dapat ditrempuh oleh peneliti etnografi virtual sebagai berikut:

1. Identifikasi Masyarakat Secara Proaktif Hal pertama yang dilakukan etnografer adalah memasuki komunitas virtual. Seringkali menimbulkan kesulitan bagi etnografer virtual untuk memasuki dunia komuniats virtual yang sudah mapan karena terdapat gatekeeper seperti pemilik situs, pengelolah komunitas atau pembuat aturan di komuniatas tersebut (Foster, 1994; Achmad dan Ida, 2018). Karenanya, etnografer membutuhkan strategi untuk masuk dalam komunitas yang diteliti sampai pada mengenal identitas anggota, baik dalam dunia online maupun dunia nyata.

2. Melakukan Negosiasi Akses

Setelah melakukan observasi pada komunitas virtual yang akan diteliti, selanjutnya etnografer 
meminta izin akses pada gatekeeper. Hal ini tentunya berbeda dengan etnografi konvensional, karena dalam etnografi virtual kehadiran etnografer sudah diketahui sejak awal oleh informan penelitian.

\section{Melakukan Kontak}

Dalam penelitian etnografi virtual juga dilakukan dengan observasi partisipan sehingga peneliti akan mendapatkan pengalaman dari budaya virutal. Hal ini akan memberikan wawasan teoritis dan metodologi baru (Eisenharrt, 1989; Achmad dan Ida, 2018). Achmad dan Ida (2018) menyatakan bahwa kontak yang terjadi antara peneliti dengan dunia virtual dan informan secara partisipatoris menunjukkan bahwa etnografer sudah melakukan penelitian secara sistematis dan mematahkan tuduhan penelitian yang kurang ilimiah atau sistemik. Peneliti dapat membuktikan dengan catatan-catatan dan dokumentasi selama kegiatan oabservasi partisipan dilakukan.

4. Wawancara Mendalam (Elektronik dan atau Tatap Muka) 
Teknik pengumpulan data yang dilakukan seorang etnografer virtual sama halnya dengan etnografer konvensional. Wawancara mendalam menjadi kunci kedalaman data penelitian. Wawancara dilakukan bisa dilakukan secara daring dan atau langsung. Banyak sekali media online yang dapat digunakan, seperti email, aplikasi WhatsAp dan lain sebagainya. Wawancara secara tatap muka dibutuhkan untuk mendistorsi isu orisinalitas atau penguat data online.

5. Mengembalikan Hasil dan Analisis Penelitian untuk Mayarakat

Achmad dan Ida (2018) menyatakan bahwa etnografi virtual berada pada perspektif etnografi kritis. Hasil yang didapat dari etnografi kritis dikembalikan lagi pada masyarakat, memastikan setiap perkembangan teori dan temuan mendapatkan komentar baik dan bisa dikembangkan. Hal ini berbeda dengan etnografi konvensional yang hanya cenderung mengikuti alur pengumpulan data dan analisis. Pengembalian hasil pada masyarakat ditujukan agar menghasilkan 
perubahan emansipatoris dan meningkatkan kemampuan belajar komunitas.

\section{Ringkasan}

Etnografi virtual hadir sebagai jawaban atas fenomena communication mediated computer (CMC) yang membutuhkan pendekatan penelitian dengan teori dan metode baru. Etnografi virtual tidak banyak berbeda dengan etnografi konvensional, di mana teknik pengumpulan datanya masih bertumpu pada observasi partisipan. Yang membedakan etnografi virtual dengan etnografi konvensional adalah lokasi penelitian yang berada pada dunia virtual. Hal ini menyebabkan etnongrafer virtual harus mendalami komunitas virtual yang sedang diteliti secara partisipan dan menemukan strategi pendalaman data agar dapat menganalisasi orisinalitas data etnografi virtual.

\section{Pertanyaan Evaluasi dan Diskusi}

1. Sebutkan pengertian metode etnografi virtual?

2. Jelaskan apa saja unsur yang membedakan etnografi virtual dengan etnografi konvensional? 
3. Jelaskan apa saja prinsip-prinsip dalam metode etnografi virtual?

4. Diskusikan dengan 1 teman anda bagaimana cara kita mencari data dalam sebuah komunitas bermain online?

\section{Referensi}

Achmad, Zainal, A., Ida, Rachma. (2018). Etnografi

Virtual Sebagai Teknik Pengumpulan Data dan

Metode Penelitian. The Journal of Society \& Media, 2(2), 130-145.

Hine, Cristine. (2000). Virtual Ethnography. London: SAGE Publications.

Lull, J., Chaney, David C., Gonzales, Jorge, A., Hannerz, U., Hinerman, S., Jones, S., Kucker, S., Liikkanen, M., Messaris, P., Neiva, E., Real, M., Stewart, Edwart, C. (2001). Culture In The Communication Age. Edited by James Lull. London and Ne York: Routledge.

Pearce, Celia \& Artemesia. (2009). Communities of Play: Emergent Cultures in Multiplayer Games and Virtual Worlds. London: The MIT Press Cambridge. 


\section{Biografi Penulis}

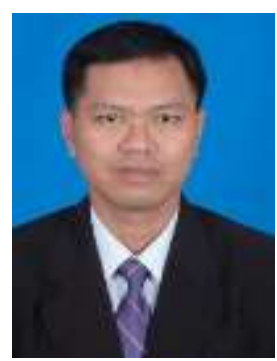

Didik Hariyanto, adalah dosen tetap pada Program Studi Ilmu Komunikasi Universitas Muhammadiyah Sidoarjo.

Aktif mengajar sejak tahun 1999 sampai saat ini. Gelar sarjana S1 Ilmu Komunikasi diperoleh dari Universitas Muhammadiyah Sidoarjo pada tahun 1998, gelar S2 dalam bidang ilmu komunikasi diperoleh pada tahun 2008 dari Universitas Dr.Soetomo Surabaya, sedangkan gelar S3 diperoleh dari program Ilmu Sosial dari Universitas Airlangga Surabaya pada tahun 2018. Aktif dalam kepengurusan organisasi publik seperti Asosiasi Pendidikan Tinggi Komunikasi (Aspikom) Jawa Timur dan menjadi konsultan di beberapa instansi pemerintahan. Penulis mempunyai peminatan di bidang Media dan Komunikasi, Pengantar Ilmu Komunikasi, Komunikasi Pemasaran, Marketing Publik Relation, Komunikasi Lintas Budaya dan Komunikasi Kebijakan. 


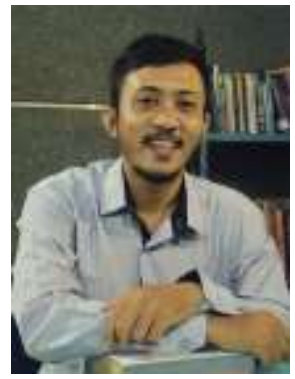

Ferry Adhi Dharma, lahir di Sidoarjo 01 Nopember 1991 tanpa seperangkat metafora. Sejak tahun 2017 penulis adalah dosen aktif di Program Studi S-1 Ilmu Komunikasi Universitas Muhammadiyah Sidoarjo.

Pada tahun 2009 penulis melangkahkan kakinya ke bangku kuliah S-1 Ilmu Komunikasi di Universitas Trunojoyo Madura setelah menyelesaikan masa remaja di SMA Muhammadiyah 2 Sidoarjo. Semasa di Madura penulis turut babat alas membangun UKM Lembaga Pers Mahasiswa (LPM) Spirit Mahasiswa (SM), yang pada tahun berikutnya (2011) dipercaya sebagai Pimpinan Umum.

Setelah itu penulis melanjutkan studi S-2 di Universitas Sebelas Maret dengan Program Studi Riset dan Pengembangan Teori Komunikasi. Di Solo penulis berjumpa dengan ilmu sosial dan budaya dalam bimbingan Prof. Andrik Purwasito, DEA. Perkenalannya itu dirasa butuh kelanjutan, sehingga di tahun 2017 penulis melanjutkan studi S-3 Ilmu Sosial di Universitas Airlangga. 
15BN $978-623-6833-025$

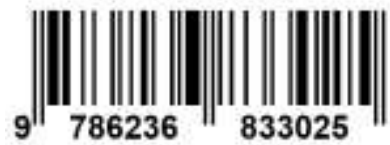

